\title{
FORAGING MODELS, NICHE CONSTRUCTION, AND THE EASTERN AGRICULTURAL COMPLEX
}

\author{
David W. Zeanah
}

\begin{abstract}
Some proponents of niche construction challenge the validity of optimality models for investigating agricultural origins, but offer no alternative strategy for understanding the economic context of human foraging decisions. They refer to the Eastern Agricultural Complex as an example of how seed cultivation can result from resource enhancement rather than population-induced resource depression, contradicting a prediction inferred from the prey choice model. Low-return seed cultigens were harvested in environments offering more highly ranked hickory nuts in abundance, apparently supporting their interpretation. A marginal value model demonstrates that in years of low mast yield, foragers could more profitably fill food stores from nearby seed plots than from distant hickory trees. Cultivating seeds would have been economically worthwhile when population circumscription constrained mobility, consistent with trends indicating regional population growth. Surges in walnut shell relative to small seeds are also consistent with the model, suggesting that foragers intensified their use of local, anthropogenic vegetation communities as populations grew, stimulating development of horticultural economies. This illustrates the value of foraging models used in conjunction with niche construction for investigating agricultural origins, particularly when model predictions initially fail to accord with archaeological evidence.
\end{abstract}

Algunos defensores del modelo de construcción de nicho disputan la validez de los modelos de estado óptimo en la investigación de los orígenes de la agricultura; sin embargo, no ofrecen una estrategia alternativa para comprender el contexto económico de las decisiones de forrajeo humanas. Estos investigadores utilizan el Complejo Agrícola Oriental como ejemplo de la posibilidad de que el cultivo de semillas pudo haber resultado de la mejora de recursos en lugar de la depresión de recursos inducida por el crecimiento poblacional, lo cual contradice una predicción inferida del modelo de elección de presas. Las semillas de bajo retorno fueron cosechadas en ambientes que ofrecían fuentes de nutrición preferenciales tales como las nueces de nogal en abundancia, aparentemente apoyando estas interpretaciones. Un modelo de valor marginal demuestra que en años de bajo rendimiento de nueces, los recolectores pudieron haber llenado sus depósitos de los semilleros cercanos con más facilidad que si hubieran aprovechado los nogales lejanos. En consistencia con tendencias que indican un crecimiento demográfico regional, el cultivo de semillas habría adquirido valor económico cuando la circunscripción limitaba la movilidad. Los aumentos repentinos de cáscaras de nuez en relación a las semillas pequeñas también son consistentes con este modelo, el cual indica que los recolectores intensificaron la utilización de comunidades vegetales antropogénicas mientras crecía la población, estimulando así el desarrollo de economías hortícolas. Esto ilustra el valor de los modelos de forrajeo utilizados en combinación con la construcción de nicho en la investigación de los orígenes agrícolas, sobre todo cuando las predicciones del modelo no concuerdan con la evidencia arqueológica.

$\mathrm{T}$ he Eastern Agricultural Complex (EAC) emerged as an independent center of plant domestication in an interior riverine region of the United States that offered abundant natural resources (Figure 1). Indigenous annual grasses and forbs domesticated before maize became the dominant crop about 1,100 years ago included squash (Cucurbita pepo ssp. ovifera), sunflower (Helianthus annииs var. macrocarpus), marshelder (Iva annua var. macrocarpa), and chenopod (Chenopodium berlandieri) (Smith 1989, 2006, 2011; Smith and Yarnell 2009). Giant ragweed (Ambrosia trifida), little barley (Hordeum pusillum), maygrass (Phalaris caroliniana), and knotweed (Polygonum erectum) were probably also cultivated (Gremillion 2004:216; Smith and Yarnell 2009:6562).

David W. Zeanah घ Department of Anthropology, California State University, Sacramento, 6000 J Street, MND 4010, Sacramento, CA 95819-6106 (zeanah@ csus.edu) 


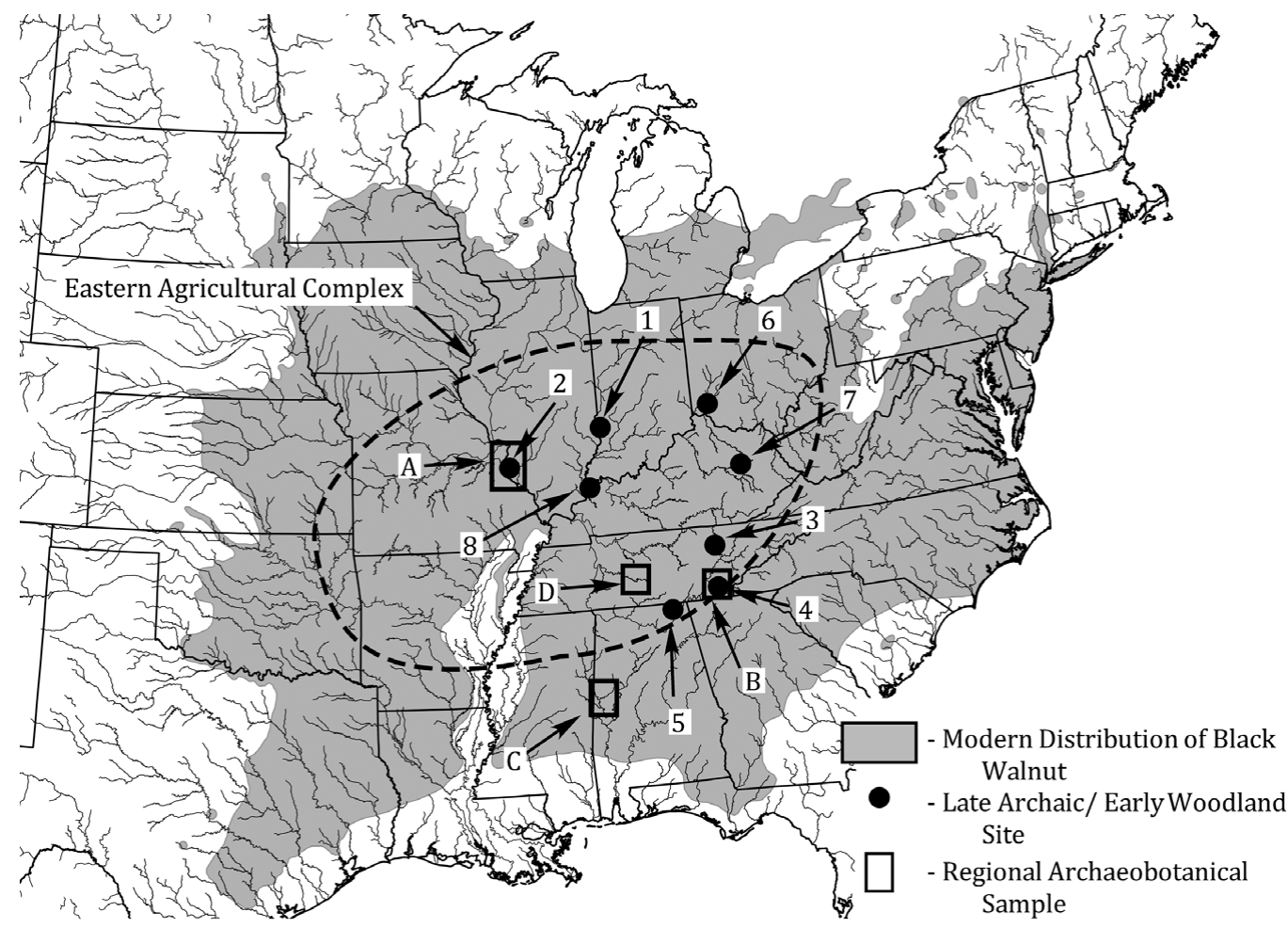

Figure 1. Map of the eastern United States showing Eastern Agricultural Complex limits after (Smith 1987b), modern distribution of walnuts, and archaeological sites/regions mentioned in the text: (1) Riverton, (2) Florence Street, (3) Phipps Bend, (4) Iddins, (5) Russell Cave, (6) Davisson Farm, (7) Cloudsplitter Rock Shelter, (8) Highland Creek; (a) American Bottom, (b) Little Tennessee River valley, (c) Tombigbee River valley, (d) Duck valley.

Applications of microeconomic logic to understanding the cost-benefits of foraging and farming in eastern woodlands span several decades (Brown and Vierra 1983; Christenson 1980, 1986; Gremillion 1998, 2006; Keegan and Butler 1987; Reidhead 1981; Stafford 1994). Winterhalder and Goland (1997) proposed a research strategy, formally grounded in human behavioral ecology that used foraging models to pose various testable scenarios by which agriculture developed in the eastern United States. One based on the prey choice or diet breadth model (Charnov and Orians 1973; Schoener 1971) suggested that population pressure depressed the abundance of higher-ranked resources, triggering small seed cultivation as diet expanded to include very low-ranked resources. However, co-occurrence of nut and acorn shell with seed cultigens in archaeobotanical assemblages seems inconsistent with a key prediction of the prey choice model: that costly resources are added to the optimal diet only when higherranked alternatives are sufficiently rare. Small seed grains probably offered only between 300 and 1,000 kcal/hr (Gremillion 2004), whereas hickory nuts (Carya spp.), hazelnuts (Corylus spp.), walnuts (Juglans spp.), and acorns (Quercus spp.), yielded between 250 and 3,500 $\mathrm{kcal} / \mathrm{hr}$ (Gremillion 2002b; Petruso and Wickens 1984; Talalay et al. 1984; Thomas 2008) in an autumn collecting window that overlapped most seed harvests. Gremillion (2002a, 2002b, 2004, 2006) demonstrated that the EAC cannot be understood simply as an expansion of diet breadth because of the abundance of mast, and proposed that seed cultivation buffered risk resulting from inter-annual variability in mast yields. Archaeologists working in the behavioral ecology paradigm have since emphasized the storability of seeds by modeling central place 
foraging, risk, and transport costs (Carmody 2010, 2014; Gremillion 2002b, 2004; Thomas 2008)

Smith (2015) recently advocated niche construction as a superior evolutionary framework for investigating the EAC. Niche Construction Theory argues that organisms modify the ecological context of natural selection, and that subsistence adaptations arise from feedbacks between organisms and their environment rather than from one-way adjustments of foraging behavior to shifting resource configurations, as implicitly assumed in optimality models. As paramount niche constructors, humans apply cultural knowledge to enhance foraging productivity, leading, in some instances, to domestication. Under this framework of Cultural Niche Construction (CNC), Smith (2015:250) argues that the EAC is better understood as resource enhancement under conditions of plenty than a response to resource shortfalls induced by population growth. His reasoning harkens back to historical disputes over whether population pressure (Binford 1968) or cultural change (Braidwood 1960) stimulated the development of broadspectrum foraging and Neolithic economies (Miller 2014; Zeder 2012). It challenges foraging theory only to the extent that the prey choice model formalizes long-held expectations about the effects of demographic pressure on resource selection (Cohen 1977; Flannery 1969) in a testable manner (Winterhalder and Kennett 2006). Nonetheless, Smith (2015) claims that lack of archaeological evidence for population pressure prior to the earliest evidence of seed domestication not only falsifies this resource depression hypothesis for the origin of the EAC, but also calls into question fundamental premises underlying optimality models altogether.

In this paper, I critique Smith's application of $\mathrm{CNC}$ and contend that, lacking means of modeling human foraging choices, $\mathrm{CNC}$ relies instead on economically naive assessments of resource abundance. I apply the marginal value theorem to EAC food storage strategies to model circumstances in which seed harvest and cultivation were economically worthwhile when reduced mobility and high travel costs restricted access to higher-ranked hickory nuts. I test a hypothesis that a shift from hickory to walnut occurred prior to the intensification of seed crops because it offers higher harvest rates than small seeds. Contrary to Smith's critique, I find that a research strategy based on foraging models is essential for understanding the EAC in the context of niche construction.

\section{Prey Choice Model Predictions for Hickory and Chenopod Seed}

The explanatory dilemma posed for the resource depression hypothesis is exemplified by comparing post-encounter return rates (calories acquired per time spent pursuing and processing a resource) of hickory nuts and chenopod seed. These are often the most abundant and ubiquitous macrofossils in respective nut and seed cultigen categories in archaeobotanical assemblages (Gremillion 2003; Scarry 2003; Simon 2009), but they differ significantly in their caloric returns. When processed for oil, hickory nuts were probably the highest ranked mast crop. Thomas's (2008) experiments demonstrated that pignut hickory (Carya glabra) could yield in excess of $2,000 \mathrm{kcal} / \mathrm{hr}$, which is a conservative estimate for hickory oil (Gremillion 2002a; Talalay et al. 1984). In contrast, chenopod probably offered only about $600 \mathrm{kcal} / \mathrm{hr}$ (Gremillion 2004), as inferred from ethnographic handling times for an Australian chenopod (Cane 1987). Although not based on experimentation with Chenopodium berlandieri, this estimate is consistent with various ethnographic and experimental sources for small-grain seeds (Seeman and Wilson 1984; Simms 1987; Zeanah et al. 2015), and probably accurately ranks chenopod seed as offering significantly lower caloric returns than hickory oil, unless further actualistic evidence demonstrates substantially more effective traditional harvest and processing techniques (López et al. 2011).

Although skepticism of the precision of these return rates is warranted, using them to algebraically solve for search time (Bettinger 2009) suitably illustrates the problem they pose for the resource depression hypothesis. A hypothetical forager seeking to optimize energetic return rate should bypass a stand of chenopod unless it takes more than eight hours to find the next productive hickory tree: an unrealistic 
assessment given the abundance of hickory, as well as alternative highly ranked species of oak, in eastern woodlands (Keller 1987; Zawacki and Hausfater 1969). Although nut yields vary annually, locations of productive crops can be anticipated in advance of harvest (Gardner 1997; Nixon et al. 1980), and prehistoric foragers likely enhanced mast yields by controlled burning and silviculture (Abrams and Nowacki 2008; Gardner 1997; Smith 2009a; Wagner 2003). The prey choice model thus reveals little incentive for prehistoric foragers to harvest seeds if they were free to move where they knew nuts and acorns to be accessible.

\section{Niche Construction Theory and the EAC}

Smith's (1987a, 1995) Floodplain Weed hypothesis describes the domestication of small seeds as a sequence of niche construction processes. As Middle Holocene climate stabilized fluvial depositional systems, regular flooding opened sandy habitats that fostered annual weeds, including chenopod. Smith (1995:202-203, 2011:S477) expects that foragers residing nearby would have harvested these grasses because of their natural abundance and yield. Seeds also thrived in anthropogenically disturbed habitats near riverine base camps, initiating coevolutionary relationships with human foraging activity as early as the Middle Archaic (8900-5800 cal B.P.). ${ }^{1}$ Domestication resulted from intentionally replanting seed stock on recently exposed floodplains. Although morphological indicators of domestication, such as seed coat reduction in chenopod, appear by the Late Archaic (5800 3200 cal B.P.), cultivated seeds remain minor components of archaeobotanical assemblages until the Woodland period (3200-1000 cal B.P.), when more intensive horticultural subsistence economies emerge. Smith (2001:18) characterizes the preceding adaptation as low-level food production in which cultivated seeds made only minor contributions to otherwise broad-spectrum foraging economies. Although he recognizes that population pressure may have played a role in the Woodland horticultural intensification (Smith 1987a:25), he challenges any notion that it triggered the earlier Archaic domestication of seeds (Smith 1995:211-212, 2015 249-250).
Smith (2011) uses the Late Archaic Riverton site in Illinois to support this interpretation. He understands Riverton as a base camp for a multifamily group based on various residential, storage, and midden features exposed in excavation (Smith and Yarnell 2009; Winters 1969; Yarnell 2004). At least three species of annuals in the archaeobotanical assemblage were domesticated by 3800 B.P., but foragers at Riverton also harvested diverse terrestrial and riparian game, a variety of nuts, and seeds of at least five nondomesticated plants, most indicating autumn occupation (Yarnell 2004). Smith (2011:S482) argues that appearance of domesticated seed morphologies at Riverton is evidence that the EAC emerged in resource-rich, riverine environments free from resource depression.

Other than this, Smith (2015:240) relies heavily on "absence of evidence" for resource depression and population growth in archaeological contexts. For example, Smith (2011:S482) argues that demographic pressure did not precede seed domestication because the three Late Archaic residential sites located by Winters (1969) along the Wabash River, including Riverton, are spaced $16 \mathrm{~km}$ apart and buffered by ample upland catchments. Yet it is unclear to what degree this site density simply reflects preservation and sampling biases in fluvial settings (Stafford 1994). Further, it is not selfevident that contemporaneous occupation of the three sites would be insufficient to depress highranked resources locally. One could argue to the contrary that the number of residential structures and investment in their construction, the extent of refuse disposal in middens, and the diversity of subsistence resources at Riverton are direct evidence of tethered residential mobility and broad spectrum foraging, consistent with local demographic packing and resource depression. Smith poses no further criteria by which resource depression or enhancement can be distinguished or measured at Riverton.

It is unclear why foragers would cultivate seed plots in environments already prolific in wild seeds and mast. Smith (1987a:27-29) suggests that sedentary occupation of riverine locations, like Riverton, was prerequisite for domestication, and that spring replanting of seed stock ensured household security and social affluence 
Table 1. Estimates of Resource Productivity.

\begin{tabular}{llll}
\hline & \multicolumn{1}{c}{ Hickory } & \multicolumn{1}{c}{ Chenopod } & \multicolumn{1}{c}{ Walnut } \\
\hline Energy kcal/kg & $7,000^{\mathrm{a}}$ & $3,200-4,000^{\mathrm{b}}$ & $6,070^{\mathrm{c}}$ \\
Harvest Rate (kg/hr.) & $57.04(\mathrm{nuts})^{\mathrm{a}}$ & $1-1.5$ (achenes $^{\mathrm{d}}$ & $5.2-9.5(\text { nuts })^{\mathrm{e}}$ \\
\% Edible & $12^{\mathrm{a}}$ & $72^{\mathrm{c}}$ & $19^{\mathrm{f}}$ \\
Harvest Return Rate (kcal/hr.) & 47,900 & $2,300-4,300$ & $6,000-11,000 \mathrm{kcal} / \mathrm{hr}$. \\
Yield (kg/ha) & $12^{\mathrm{c}}$ & $1,300^{\mathrm{d}}$ & $1.1^{\mathrm{c}}$ \\
Yield (kcal/ha) & 84,000 & $5,200,000$ & 6,677 \\
Hectares/Caloric Requirement $(8,400,000)^{\mathrm{d}}$ & 100.0 & 1.6 & $1,258.1$ \\
\hline
\end{tabular}

aThomas 2008:Table 8.1.

${ }^{\mathrm{b}}$ Asch and Asch 1978:Table 1; Smith 1992:198).

${ }^{\mathrm{c}}$ Gremillion 2002b:Table 1.

${ }^{\mathrm{d}}$ Smith 1987a, 1992:Table 3 .

eTalalay et al. 1984:Table 3 .

${ }^{\mathrm{f}}$ Talalay et al. 1984:Table 1.

(Smith 1995:211-212). But these explanations merely raise the question of why households resided year-round in locations where their security and affluence were uncertain. As currently constructed, CNC offers no archaeologically testable hypotheses for why the EAC emerged as a successful and sustained subsistence strategy when and where it did. Without a theoretical framework that generates expectations about human behavior, niche construction falls back on economically naive descriptions of resource abundance.

To illustrate, Smith's (1992:198) estimates of field productivity suggest that a plot of chenopod $16,900 \mathrm{~m}^{2}$ in area could supply an extended family of 10 with their entire annual caloric needs (Figure 2; Table 1), presumably motivating that family to cultivate chenopod. But that same caloric target could be more easily met by harvesting a productive hickory grove measuring only $1.2 \mathrm{~km}$ in diameter, using common estimates of mast yields (Gardner 1997; Gremillion 2002b). Either scenario unrealistically assumes that hickory and chenopod yields were consistent from year to year, and that humans could harvest 100 percent of either crop. Various species of hickory are found in both lowland and upland climax forests (Talalay et al. 1984) and mast every few years with crops as much as 14 times the yields of intervening years (Nixon et al. 1975:Table 11). Hickory, walnut, and oak trees tend to synchronize mast regionally both in response to climate, and as an adaptive strategy to periodically starve, and then overwhelm, nucivorous birds and mammals (Koenig and Knops
2005; Nixon et al. 1975; Nixon et al. 1980; Smith and Scarlett 1987). As a result, prehistoric human foragers faced cycles of bumper crops separated by years of relatively poor harvest, when they competed with a variety of other animals to collect nuts before they spoiled (Gardner 1997; Hollenbach 2009; Keller 1987; Neumann 2002). The prime window for collecting hickory was thus restricted to three or four weeks following the first autumn frost (Petruso and Wickens 1984; Talalay et al. 1984). Chenopod seeds can be harvested at the same time as hickory, but linger on stalks after the autumn mast harvest (Hollenbach 2009; Seeman and Wilson 1984). This suggests that one advantage for chenopod cultivation may have been to supplement nut and acorn shortfalls in poor years (Gremillion 2004).

Yet short of a catastrophic regional mast failure, mobile foragers should have been able to satisfy their caloric requirement with hickory nuts within the catchment that Smith (2011:S482) proposes for Riverton. For example, Figure 3 illustrates $10-\mathrm{km}$ catchment radii of three Archaic to Late Woodland sites in westcentral Alabama (Caddell 1981). Boundaries and tree composition of four vegetation zones were estimated from nineteenth-century General Land Office Survey records. Table 2 depicts percent composition of hickory trees in each community, estimating the number of hickory trees within the catchment of each site. Assuming 50 trees of all types per acre (Keller 1987), if only half of the hickory trees produced nuts each year (Gremillion 2002) and a poor production year yielded only 5 percent of a bumper crop (Nixon et al. 


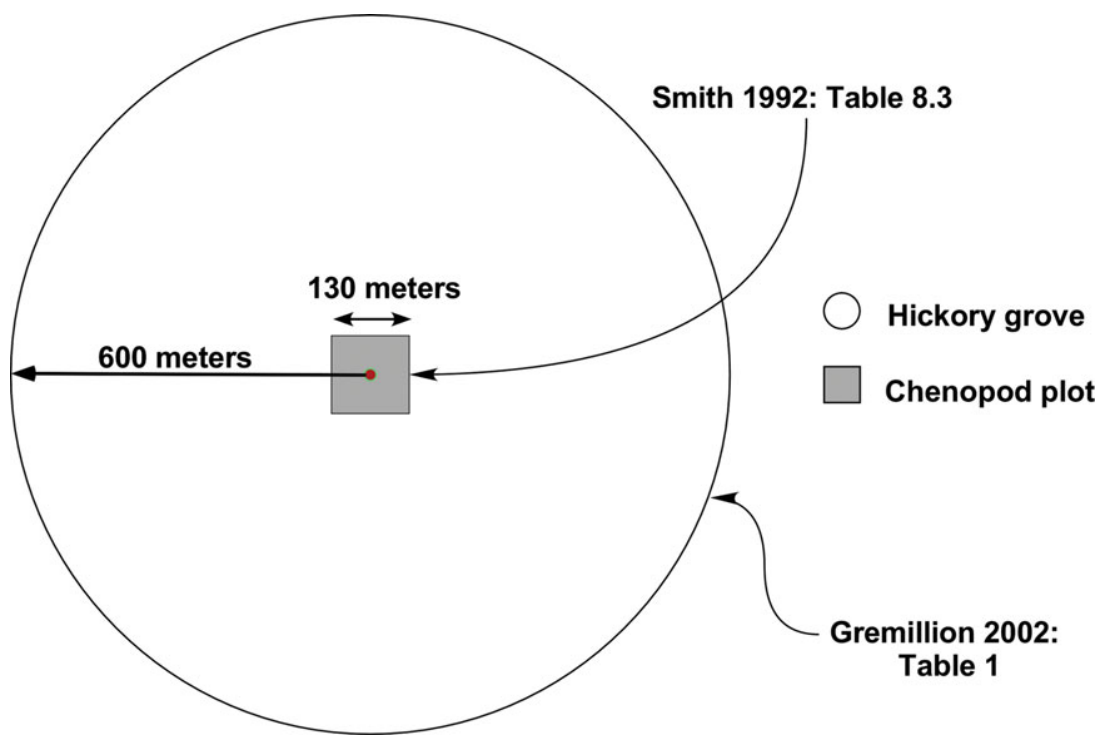

Figure 2. Catchments of chenopod and hickory needed to fulfill annual household caloric requirement (Gremillion 2002b; Smith 1992). (Color online)

Table 2. Hickory Nut Yields for 10-km Catchment Basins of Three Sites.

\begin{tabular}{|c|c|c|c|c|c|}
\hline Vegetation Zone & $\%$ Hickory & Catchment A & Catchment B & Catchment C & Total $^{\mathrm{a}}$ \\
\hline Floodplain Forest $\left(\mathrm{km}^{2}\right)$ & 16.4 & 65 & 135 & 111 & 217 \\
\hline Slope Forest $\left(\mathrm{km}^{2}\right)$ & 13.9 & 114 & 83 & 88 & 321 \\
\hline Upland Forest $\left(\mathrm{km}^{2}\right)$ & 8.8 & 83 & 67 & 65 & 229 \\
\hline Grassland $\left(\mathrm{km}^{2}\right)$ & 0 & 28 & 16 & 16 & 72 \\
\hline Total \# Hickory Trees ${ }^{\mathrm{b}}$ & & 417,554 & 488,727 & 446,527 & $1,239,434$ \\
\hline Total Productive Trees ${ }^{c}$ & & 208,777 & 244,363 & 223,263 & 619,717 \\
\hline Edible Nuts (kcals) ${ }^{\mathrm{d}}$ & & $104,388,375$ & $122,181,638$ & $111,631,650$ & $309,858,413$ \\
\hline Total Harvest (kcals) ${ }^{\mathrm{e}}$ & & $10,438,838$ & $12,218,164$ & $11,163,165$ & $30,985,841$ \\
\hline Households Supported $^{\mathrm{f}}$ & & 1.2 & 1.5 & 1.3 & 3.6 \\
\hline
\end{tabular}

Note: From Caddell (1981:53-57) unless noted.

${ }^{\mathrm{a}}(\mathrm{A}+\mathrm{C})+((\mathrm{A}+\mathrm{C})-\mathrm{B})$.

${ }^{b}$ Keller 1987:179.

${ }^{c}$ Gremillion 2002b:Table 1.

${ }^{\mathrm{d}}$ Nixon et al. 1975:Table 11; Nixon et al. 1980:535-536.

${ }^{\mathrm{e}}$ Keller 1987:181.

${ }^{\mathrm{f}}$ Smith 1992:198.

1975:Table 11), of which only 10 percent was harvestable (Keller 1987), the 10-km catchment surrounding the three sites should, nonetheless, have yielded enough nuts to sustain nearly four of Smith's (1992:198) extended families. Given that prehistoric foragers could have supplemented hickory nut shortfalls with acorns higher-ranked than seeds (Gremillion 2002b; Thomas 2008), it is difficult to envision niche construction scenarios, lacking population-induced resource depression, where cultivating chenopod proved economical.

Smith's (2015:250) resource enhancement hypothesis clearly faces the same explanatory quandary as does the resource depression hypothesis in that it fails to pose any specific advantage for enhancing the abundance of an expensive resource in an environment where better resources were already predictable and abundant. What economic incentive foragers had 


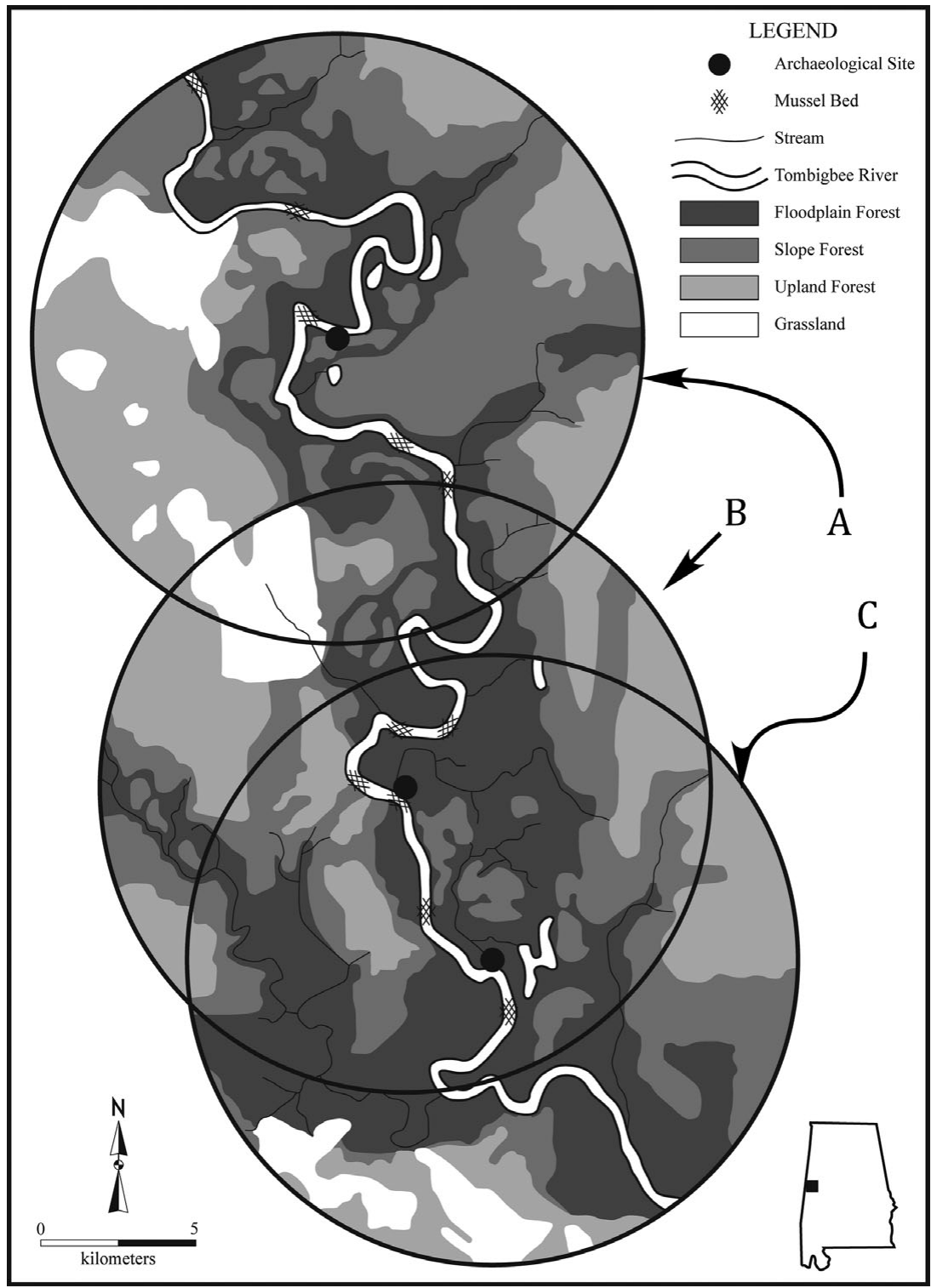

Figure 3. GLO vegetation zone reconstruction of $10-\mathrm{km}$ catchment radii of three base camps in the central Tombigbee River valley of Alabama (after Caddell 1981:Figure 1).

to use, much less to cultivate, small seeds in environments rich in mast remains ambiguous. Instead, cultivation is contradictorily asserted to be a means of enhancing the abundance of naturally abundant seed grasses (Smith 1995:211212, 2011:S477). CNC is then assumed confirmed, simply by virtue of observing evidence of seed domestication and anthropogenic habitat modification in circumstances judged, based on the absence of evidence, as lacking resource depression (Smith 2015:240).

\section{Foraging Models as an Archaeological Research Strategy}

Archaeologists face serious challenges in applying optimal foraging models, which are designed to predict individual foraging choices contingent 
on short-term resource fluctuations, to long-term subsistence changes in the archaeological record. They must be wary of site formation biases and take care that proxy measures of foraging efficiency accurately monitor prehistoric foraging choices. Nonetheless, when employed in the framework of behavioral ecology, archaeological applications draw from an impressive body of hunter-gatherer research, bolstered by careful attention to ethnoarchaeology and middle-range theory (see Bird and O'Connell [2012], Codding and Bird [2015] for recent overviews of the approach).

Smith (2015:38-39) questions the validity of optimality models as evolutionary theory because they draw from microeconomic thinking and assume that foragers make rational choices. His critique reflects a misunderstanding that optimality models are empirical generalizations, rather than heuristic devices that generate testable hypotheses about foraging behavior (Gremillion et al. 2014). The prey choice model, for example, assumes that foragers randomly encounter resources in proportion to their abundance in the environment, and that search and handling costs are mutually exclusive; time spent pursuing and processing one resource cannot be spent searching for another (Charnov and Orians 1973). Simplifying foraging complexity in this manner allows one to pose trade-offs between search and handling costs, predicting the best choice of resources that a forager should take to optimize their caloric return rate. Whether or not a forager should consume an encountered resource depends on the scarcity of higherranked prey, and low-ranked resources fall in or out of the best choice set as the abundance of higher-ranked resources fluctuates. Thus, the abundance of low-ranked seeds alone could not have offered sufficient incentive for huntergatherers to harvest, much less cultivate, them if immediate caloric foraging efficiency was their goal.

This is not a law-like generalization but a prediction that will be supported only if the assumptions of the model adequately reflect the foraging options of a test case. The hypothesis that the EAC was triggered by depression of higher-ranked resources resulting from climatemediated population growth was informed by this prediction (Winterhalder and Goland 1997). If archaeological research has successfully falsified this hypothesis by demonstrating that resource depression did not occur, then it has been a successful application of the prey choice model. The next step, in an effective research strategy based on optimal foraging models, is to consider whether assumptions about the spatial structure of foraging (random encounters with simultaneously available resources), constraints (conflicts between search and handling costs), and goals (momentary optimization of energetic return rates), accurately track EAC foraging options. In this sense, Smith's (2009b:533534) claim that the prey choice model fails to realistically capture economic choices when hunter-gatherers construct niches is closer to the mark. Seeds and mast occur in spatially discrete patches during overlapping, but not concurrent, seasonal harvest windows. Central place foragers choose which patch to harvest rather than randomly encountering them, and their goals include food storage rather than immediate consumption alone. Failure of prey choice model predictions to accord with archaeological evidence should, therefore, highlight these other foraging constraints and goals as potentially critical and generate further test implications against archaeological, ethnographic, and actualistic evidence.

Following this research strategy requires modeling alternative foraging constraints that convincingly capture the foraging choices that stimulated the EAC. Bird and O'Connell (2012:47) point out that successful elucidation of broad-spectrum transitions using foraging theory depend on a clear statement of the question, selection of an appropriate model, and actualistic work that supplies information about how to measure the model's variables. I follow that approach here by using the marginal value theorem and central place foraging to assess the cost/benefits of prehistoric foraging decisions related to the storability and transportability of chenopod and hickory. I then discuss implications of the marginal value theorem for investigating economic contexts under which seeds were collected and cultivated, and cast a hypothesis about a previously poorly understood trend in walnut use that corresponds with the 
emergence of horticultural economies based on the cultivation of annual seeds.

\section{The Marginal Value Theorem, Central Place Foraging, and Food Storage in the EAC}

I make several assumptions about foraging choices in the eastern woodlands. Prehistoric foragers choose whether to harvest hickory or chenopod from a central place rather than search for them on a foraging trip. This means that round-trip travel time, a cost not monitored in the prey choice model, must factor into modeling their best choice (Carmody 2014; Gardner 1997:167; Hollenbach 2009; Purtill 2008). Since foragers could either intentionally cultivate chenopod or harvest it wild from anthropogenic disturbances, I assume that the chenopod plot is always close to home, whereas hickory trees are ubiquitously scattered throughout the environment. The objective is to harvest food for storage within a limited span of time so that prehistoric foragers could postpone further processing to avoid forfeiting further harvesting opportunities. Therefore, harvesting time is the only pertinent handling cost for this specific model (Gremillion 2004; Tushingham and Bettinger 2013), although full processing costs should influence longer-term foraging decisions. This approach differs from some previous attempts to reckon travel and transport costs that assumed higher levels of processing prior to transport (Carmody 2014; Hollenbach 2009; e.g., Zeanah 2002). ${ }^{2}$

In years of poor hickory yield, foragers needed to travel farther to harvest more diffuse hickory nuts and return them to storage locations. Foragers should prefer efficiently handled hickory crops over seeds only when willing to pay additional harvest, travel, and transport costs necessary to gather more widely dispersed nuts. The foraging question then is simple: how distant must the next productive hickory tree be before a forager finds it more efficient to harvest a nearby patch of chenopod? To model this tradeoff, I use Bettinger and Grote's (2016) formulation of the marginal value theorem incorporating harvesting time as a variable.

There are robust actualistic estimates of collection rates for both chenopod and hickory.
Thomas (2008) reports a harvest rate for hickory nuts of $57.04-\mathrm{kg} / \mathrm{hr}$ (yielding 48,000 kcal/hr without reckoning the costs of shelling the nuts) based on multiple collecting experiments. A marginal return curve for harvesting $4 \mathrm{~kg}(10,000$ kcals) of hickory nuts from a single productive hickory tree is presented in Figure 4. Smith (1987b) reports rates for harvesting uncleaned chenopod seed ranging from $1 \mathrm{~kg} / \mathrm{hr}(2,240$ $\mathrm{kcal} / \mathrm{hr}$ at $3,200 \mathrm{kcal} / \mathrm{kg}$ of clean seed) to $1.5 \mathrm{~kg} / \mathrm{hr}$ $(4,400 \mathrm{kcal} / \mathrm{hr}$ at $4,000 \mathrm{kcal} / \mathrm{kg}$ of clean seed). Chenopod seed can occur in greater densities than hickory nuts (Table 1), but our hypothetical forager should nonetheless prefer hickory to seeds, because the former can be harvested at a significantly higher rate as long as the next productive hickory tree is not too far away. The threshold at which harvesting chenopod becomes economical is predicted in Figure 4 by plotting lines at the upper and lower rates of chenopod harvest, and tangent to the hickory curve. Using Smith's (1987b) lowest chenopod harvest rate as a conservative estimate of what was feasible in wild, low-density seed stands, the intercept of the line with the $\mathrm{x}$-axis (about 180 minutes) is the predicted point at which harvesting nearby chenopod becomes worthwhile. At a walking speed of $3 \mathrm{~km} / \mathrm{hr}$, chenopod begins to look good if the next productive hickory tree is more than $4.4 \mathrm{~km}$ away. At distances less than $4.4 \mathrm{~km}$, our forager can walk to the hickory, harvest, and return with a load of nuts at a rate greater than that obtained from a local harvest of chenopod. When hickory trees are more than $4.4 \mathrm{~km}$ away, food stores are more effectively filled with chenopod. Phrased another way: foragers attempting to efficiently fill winter larders in a limited time should collect hickory exclusively until the overall harvest rate (including round-trip travel time) in the surrounding catchment drops below the $2,300-4,300 \mathrm{kcal} / \mathrm{hr}$ rate obtainable from nearby seed stands. This prediction is realistic for the scale of human foraging in eastern forests and suggests that human foragers could have economically switched from harvesting hickory to wild chenopod seeds in years of a poor hickory yield after depleting nearby hickory stands well within the 8- to 10-km foraging radius Smith proposes for sites along the Wabash or illustrated in Figure 3. 


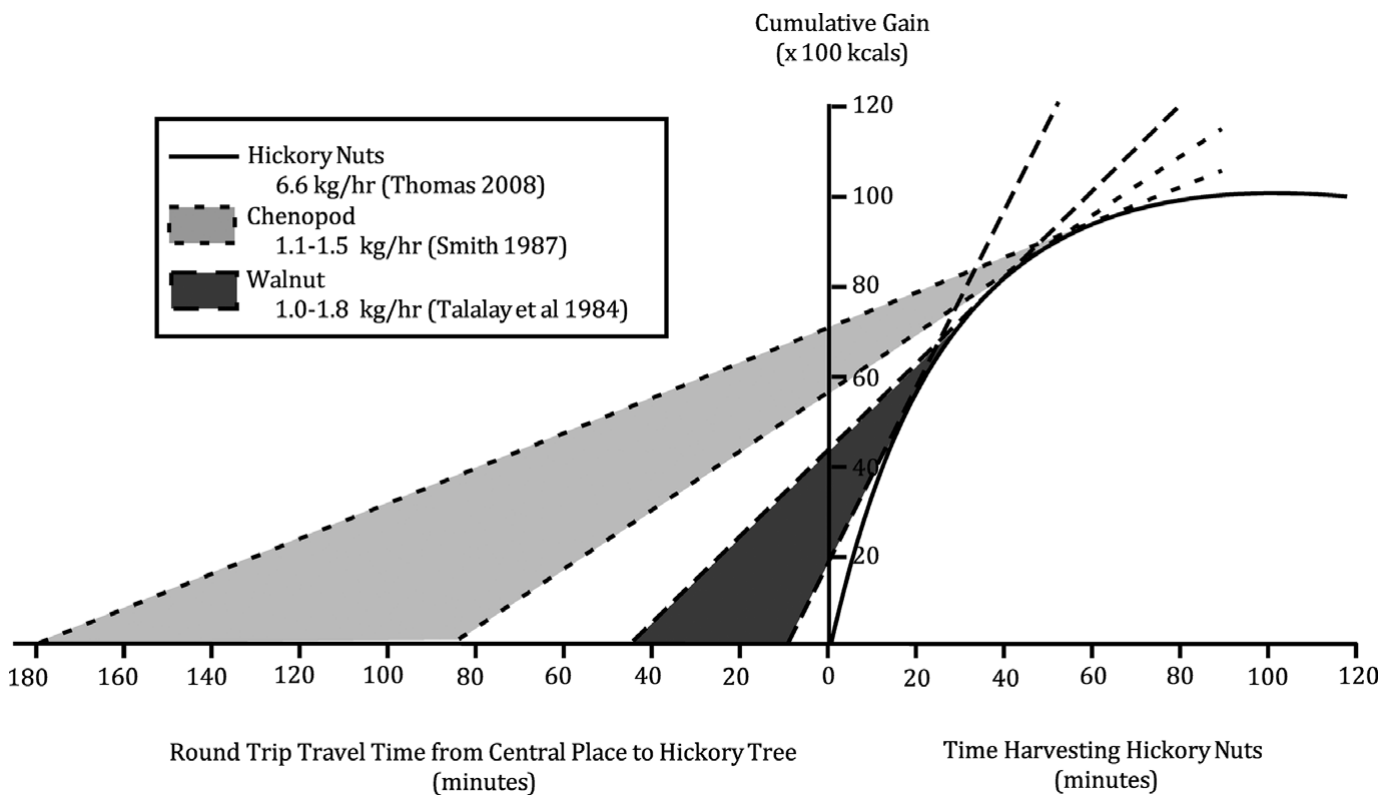

Figure 4. Marginal value model for hickory harvests. In-patch harvest time and yield to the right of the axis and round-trip travel time between a central place and hickory patch to the left. The curve for hickory (solid line) is calculated assuming a search area of $1000 \mathrm{~m}^{2}$ and yield of $10,000 \mathrm{kcal}$ allocated in $100,100 \mathrm{kcal}$ lots per hickory tree (cf. Gremillion 2002b). It takes about 17 minutes to fully search the patch, and nuts can be harvested at a maximum rate of 8 units per minute (Thomas 2008). Dashed lines show travel thresholds below which it becomes economical for a forager to harvest a nearby walnut tree or chenopod patch rather than travel to the next hickory tree. At travel times less than these thresholds, foragers should harvest only hickory nuts to maximize their harvest rate.

Smith's (1992:198) higher harvest rate of $1.5 \mathrm{~kg} / \mathrm{hr}$ is a better approximation of the rate at which foragers could harvest cultivated chenopod because of the greater density of plants that could result in planted and tended plots. If this is correct, the effective foraging radius for hickory trees from cultivated plots is merely 74 minutes or a little over $1.8 \mathrm{~km}$ away (Figure 4 ), suggesting that one economic benefit of cultivation was to enhance the harvest rate of local but more costly resources, in order to minimize transport of more distant alternatives for storage. Constraints on mobility seem to be a likely cause, and foraging theory can be used to envision testable scenarios in which foragers would have found that choice economical.

\section{Implications for Anthropogenic Niche Construction and Small Seed Cultivation in Southeast Prehistory}

Travel and transport costs were demonstrably long-standing constraints on hickory nut storage strategies. Prehistoric foragers began intensively storing and bulk processing hickory nuts for oil by the Middle Archaic (Homsey et al. 2010; Moore and Dekle 2010; Munson 1986; Stafford 1991). With rare exceptions thereafter, hickory is the dominant nutshell in Archaic macrofossil assemblages (Scarry 2003; Simon 2009; Yarnell and Black 1985), consistent with the prey choice model prediction that high-return resources should always be taken (Carmody 2010). Archaic autumn hickory nut procurement strategies were organized logistically and included residential moves to productive upland hickory woodlands (Carmody 2010; Gardner 1997; Jenkens 1974; Stafford 1991). Archaic foragers thus had the option to either residentially map onto the most productive hickory groves or temporarily cache hickory at field camps and delay logistic transport until after the harvest season.

Riparian shell middens also first appear in the Middle Archaic, suggesting spring-summer occupation near productive shellfish beds, 
waterfowl hunting, and fishing locations (Anderson et al. 2007). Annual weeds would have been abundant in naturally disturbed floodplains near these sites, as well as in open habitats left by fire (Smith 1987a, 1995). Pollen records show increases in fire-tolerant trees, the emergence of patchworks of open areas, and successional stages of forest cover from about 5000 to 3500 B.P., reflecting the impact of human-set fires (Delcourt et al. 1998; Gremillion 2015; Jefferson et al. 1982; Wagner 2003; Whitehead and Sheehan 1985). The marginal value model for hickory transport developed in this paper (Figure 4) suggests that wild seed patches fostered by both natural and anthropogenic processes may have been economical to harvest for storage in years of low mast yields, even in circumstances lacking population-induced resource depression. Nonetheless, the advantages of harvesting wild seeds had to outweigh the benefits of simply moving to locations where higher mast yields were obtainable. Since the time necessary to fully process stored seeds for consumption surely detracted from the time available for alternative winter economic, social, and ritual activities, the significantly higher return rates offered by stored hickory nuts must have strongly favored mast over seed harvest. Minor occurrences of annual seeds in Archaic archaeobotanical assemblages (Simon 2009) suggest that foragers of the Middle Archaic, living at lower population densities than their Late Archaic successors, often found mobility to harvest nuts the preferable option.

Miller (2014) and Weitzel and Codding (2016) have challenged Smith's (2011) inference that population growth did not depress resources during the Middle Archaic, and it seems unlikely that seed cultivation was common in Middle Archaic contexts lacking demographically induced constraints on mobility. Morphological indicators of domestication, such as reduced testa thickness in chenopod, are the primary evidence for seed cultivation in Archaic contexts. Smith (1987a:35) suggests that deliberate cultivation of seeds may have begun in the Middle Archaic by sowing leftover food stores onto recently flooded riparian sand banks and point bars. This would have minimized cultivation costs, but the benefit of planting in riparian contexts where seed-yielding grasses and forbs were naturally abundant is unclear. Although the emergence of anthropogenic fire regimes roughly corresponds with the earliest domesticates, seed stands were probably inadvertent or secondary consequences of fires set to improve mast yields and hunting returns (Gremillion 2015; Gremillion et al. 2008). Possibly, seed domestication resulted from increased plant competition in anthropogenically exposed seedbeds rather than intentional planting (Smith 1987a:34).

Nonetheless, the model of marginal returns of hickory transport (Figure 4) suggests scenarios in which the cultivation of seeds may have proven adaptive in contexts lacking population pressure. Archaic foragers may have cultivated seeds if their access to higher-ranked resources (i.e., fish, waterfowl, and terrestrial game) or their social activities (Claassen 2010; Moore and Dekle 2010) limited feasible overwinter bases to locations that were anticipated to yield meager mast crops. Such measures may have been undertaken in riparian locations, as Smith and others (Brown and Vierra 1983) suggest, inviting comparison of riparian occupation sites yielding evidence of Archaic seed domestication (Smith 2011) with those where such evidence is scant (Marquardt and Watson 2005). Residential constraints would also have been important in uplands, where carrying burden baskets in wooded, rugged terrain imposed additional costs on hickory transport (Carmody 2014; Hollenbach 2009). This would have required caching and replanting seeds in habitats outside their natural range, facilitating domestication. This scenario is consistent with caches of domesticated seeds in upland rockshelters of the Ozark and Appalachian highlands, supporting an upland, rather than riverine genesis of the EAC (Fritz 1997; Gremillion 2004; Watson 1985). Framing hypotheses in terms of how the cost-benefits of foraging vary in different ecological settings offers a productive strategy for investigating the macro-regional forest-type associations that Smith (2011:S473, 2015:248249) describes for Archaic seed cultivation.

Evidence of population growth, including greater site densities, radiocarbon dates, regional trade networks, interpersonal violence, and sedentism (Anderson et al. 2007; Jefferies 2009; Weitzel and Codding 2016) suggests that demographic pressures on resources increased 
from the Middle Archaic onward. Horticultural economies clearly drawing significant dietary contributions from seed cultivation emerged during the Woodland period (Gremillion 2002a; Smith 1989), and evidence of population growth and sedentism is strongly correlated with seed horticulture intensification (Buikstra et al. 1986; O'Brien et al. 1987). Seed macrofossils are most common in regions with at least 60 days of freezing temperatures per year, suggesting that food storage played a strong role in the development of horticultural economies (Gremillion 2002a, 2004). Demographic pressures on resources critical for food storage likely factored strongly in the intensification, if not inception, of EAC seed cultivation.

The marginal value theorem suggests that, as population grew, constrictions on mobility would have encouraged foragers to supplement low hickory yields with alternative storable resources that could be accrued locally (Bettinger and Grote 2016). Cultivation to increase the harvest rate and yield of nearby seed patches is a predictable response, but foragers should have preferred alternative nuts and acorns that could be harvested at higher rates than seeds and at lower travel costs than hickory nuts. Late Archaic through Middle Woodland food storage strategies often included a broader array of mast than Middle Archaic strategies (Gremillion 2002a, 2002b; Scarry 2003; Simon and Parker 2006), but overlapping return rates, biases in the preservation and identifiability of shell, and differences in the habitat and geographic distribution of different species obscure clear relationships with evidence of population growth. Black walnuts (Juglans nigra) appear to be an exception and, as will become evident, use of walnut relative to the development of the EAC is understandable as a form of niche construction under the marginal value model presented in this paper.

\section{Black Walnuts and the Eastern Agricultural Complex}

In addition to evidence of early seed domestication, Yarnell (2004) observed unusually abundant walnut remains in almost 70 percent of the features in the Riverton archaeobotanical assemblage, making up over 80 percent of total nutshell weight. Riverton is near the geographic center of distribution of the two species that occur in archaeological contexts: black walnut and butternut (J. cinerea). And, according to Yarnell (2004:128), Riverton is also near a major center of walnut lumber production today (Figure 1). Despite the widespread distribution of walnut trees, walnut shell is rarely a significant element of archaeobotanical assemblages. However, Yarnell (2004:128) noted that walnut is often found in Late Archaic and Early Woodland contexts, and that walnut use declined as cultivation of indigenous seed crops intensified. Elsewhere he suggests that there are clearer regional, temporal trends in walnut use than other mast crops (Yarnell and Black 1985; see also Christenson 1986). Although Yarnell (2004: 128) cautioned his observation was tentative, and that Late Archaic and Early Woodland archaeobotanical assemblages do not always contain walnut, he cited several examples of components that contain high proportions of walnut relative to hickory shell (Figure 1), including the Phipps Bend (Knott 1981) and Iddins sites in Tennessee (Chapman and Shea 1981), and the Florence Street site in Illinois (Johannessen 1983). Cloudsplitter Rockshelter (Cowan et al. 1981), the Davisson Farm site (Purtill 2008), the Highland Creek site (Rossen 2006), and Russell Cave (Carmody 2014) are additional examples where walnut remains occur in unusual abundance or ubiquity in Late Archaic or Early Woodland contexts.

Other archaeobotanists have suggested various explanations for unusual amounts of walnut in these components, including human food preferences (Caddell 1981; Cridlebaugh 1984; Johannessen 1983, 1984), environmental change (Cridlebaugh 1984), sampling error (Caddell 1981; Crites 1978; Johannessen 1983), and production of fish poisons from juglone, a toxic compound that is abundant in black walnut shell (Johannessen 1983, 1984). Smith notes walnut at Riverton, but sees it as evidence that seeds only supplemented harvest of nuts from a variety of trees (Smith and Yarnell 2009:6563). None of these explanations verify, refute, or account for the temporal correlation between walnut and small seed remains posed by Yarnell (2004). 
Walnuts are an alternative to hickory nuts for storage, but offer much lower caloric returns. The outer husk adheres tightly to the ridged inner shell and must be removed manually. Unlike hickory nuts, walnuts cannot be bulk processed by water flotation and boiling techniques because meats sink with the shell, contaminating the solution with juglone. Thus, the hard, inner shell must be broken and separated from the nut by hand. A small number of experiments indicate that the return rate for black walnut is no more than about $600 \mathrm{kcal} / \mathrm{hr}$ (Talalay et al. 1984), about the same caloric return rate as chenopod seeds. However, walnuts can be harvested at a higher rate than chenopod $(5.2-9.5 \mathrm{~kg} / \mathrm{hr}$ or about 6,000 to $11,000 \mathrm{kcal} / \mathrm{hr}$ of unshelled walnuts), so the travel time-distance thresholds at which foragers should switch from harvesting hickory nuts $(0.3-$ $1.1 \mathrm{~km}$ ) are lower than those for chenopod seed (Figure 4). Walnut shell preserves well and is relatively easily distinguished from hickory shell whenever it is present in archaeological assemblages. ${ }^{3}$ This fact suggests that the presence of walnut shell in archaeobotanical assemblages is sensitive to depression of local hickory crops and signals intensification of mast harvests and storage.

Walnut trees grow best on well-drained, but moist and deep, bottomland soils that are also fertile for small seeds. Black walnut trees are relatively resistant to fire and younger trees ( $<30$ years) often re-sprout after a burn. They do well on disturbed sites but not in closed forest canopies. They usually occur as dispersed stems rather than groves because juglone in walnut roots inhibit growth of competing trees and shrubs. Most grasses and herbaceous plants, however, are juglone tolerant. Trees yield walnuts in as few as four years but do not reach full production until 30 years (Schlesinger and Funk 1977; U.S. Department of Agriculture 2015). Walnut is abundant near historically recorded Native American villages (Black and Abrams 2001; Wykoff 1991), suggesting that they do well in anthropogenic landscapes. In short, black walnut trees are late successional components of anthropogenic niches created by burning (Wagner 2005), likely found near early successional seed stands and central places.
The marginal value model for hickory transport in Figure 4, in the context of niche construction, presents a hypothesis for the temporal correlation between walnut usage and seed cultivation proposed by Yarnell (2004). Walnuts represent an alternative costly but local, storable resource that low-mobility foragers may have chosen to harvest in lieu of more distant hickory stands (Purtill 2008). Facing low hickory yields and constricted mobility, Late Archaic/Early Woodland foragers should have preferred walnuts to seeds because they could harvest the former at a higher rate at low travel costs. Like seeds, the abundance of walnuts would have benefited from anthropogenic niche construction, but walnut trees would have been poor candidates for further intensification and domestication because of their low densities and yield (Table 1), longer time to maturation, and strong preexisting coevolutionary relationships with tree squirrels (Stapanian and Smith 1978).

\section{Test of Regional Archaeobotanical Assemblages}

Foragers initially facing constraints on mobility induced by population growth should have intensified their harvest of walnut, prior to or simultaneously with their harvest of wild seeds. Domesticated annual seeds should have later replaced walnuts as a storable food as seed horticulture intensified, either because of enhanced yields from cultivated seed plots or clearance of late successional communities to put more land into cultivation. This should be a recurrent temporal pattern in the development of the EAC, because of the preservability and identifiability of walnut shell in archaeobotanical assemblages. Four large, multiple-component, regional samples spanning Archaic through Mississippian contexts serve here to track fluctuations in walnut relative to small seed usage: American Bottom, Little Tennessee River valley, Duck and Elk valleys, and lower Tombigbee River valley (Table 3). Each is discussed individually below, excluding Mississippian components because the abundance of maize in these assemblages makes them difficult to compare to earlier components in which maize was absent or rare. 
Table 3. Summary of Pre-Mississippian Regional Archaeobotanical Databases.

\begin{tabular}{lccccl}
\hline Sample & $\begin{array}{c}\text { Sites } \\
(\mathrm{Ct})\end{array}$ & $\begin{array}{c}\text { Flotation } \\
\text { Samples (Ct.) }\end{array}$ & Volume (1) & $\begin{array}{c}\text { Carbonized } \\
\text { Weight (kg) }\end{array}$ & Reference \\
\hline American Bottom & 63 & 3,655 & 59,199 & No data & Simon and Parker 2006 \\
Little Tennessee River & 8 & 281 & 5,463 & 10,139 & Chapman and Shea 1981 \\
Duck River & 7 & 660 & 659 & 16,678 & Crites 1978, 1985; McMahan 1983 \\
Tombigbee River & 7 & 96 & 2,005 & 3,262 & Caddell 1981, 1982 \\
\hline
\end{tabular}

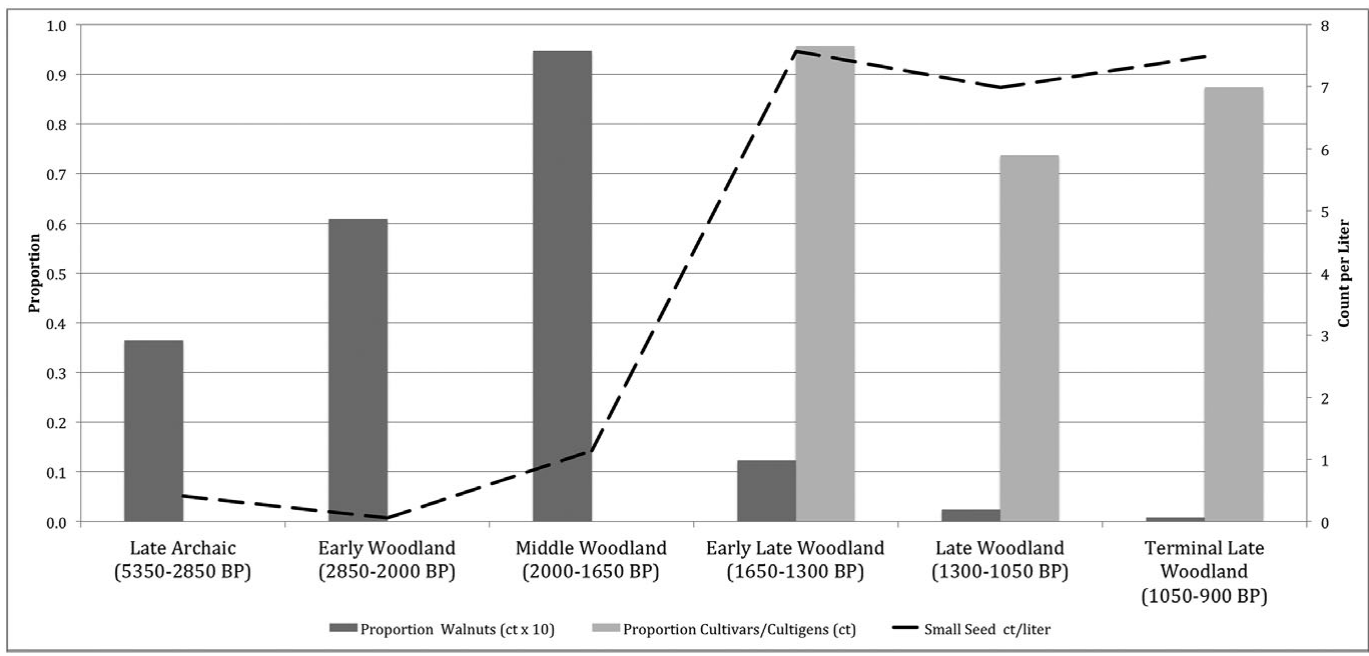

Figure 5. Temporal trends in American Bottom archaeobotanical assemblages.

\section{American Bottom}

Figure 5 illustrates trends in the American Bottom spanning local Late Archaic through Terminal Late Woodland phases (Simon and Parker 2006). The histogram indicates percent walnut of total nut count multiplied by 10 , and percent cultigen/cultivar seeds of total seed count (note that there are no data for percent cultigens before the Early Late Woodland). The line indicates total small seed count (including noncultivated species) per liter of flotation sample. Representation of walnut increases through earlier periods, reaching 6.1 percent in the Early Woodland (including 43 percent at the Florence Street site) and a peak of 9.5 percent in the Middle Woodland. This accompanies a shift in wood charcoal from bottomland to upland taxa, suggesting lowland deforestation (Johannessen 1984) and a peak in hazelnut shell, which would have been a mid-successional component of anthropogenic fire landscapes (Simon and Parker 2006). A decline in both walnut and hazelnut corresponds with a dramatic increase in small seed count (seven seeds/liter), made of 97 percent cultigen seeds, in the Early Late Woodland. Maize first appears in the Late Woodland and occurs in over 40 percent of Terminal Late Woodland samples. This trend from foraging to horticultural economies accompanies a transition from episodic occupations by semi-sedentary hunter-gatherers in the Late Archaic to large sedentary villages of complex structures in the Late Woodland (Kelly 2002), indicating reduced mobility and larger populations throughout the period that seed horticulture develops.

\section{Little Tennessee River Valley}

A similar but earlier pattern is evident in Little Tennessee River valley (Figure 6) assemblages (Chapman and Shea 1981) spanning Archaic through Middle Woodland periods (no Late Woodland occupation was identified). The occurrence of walnuts in the archaeological record 


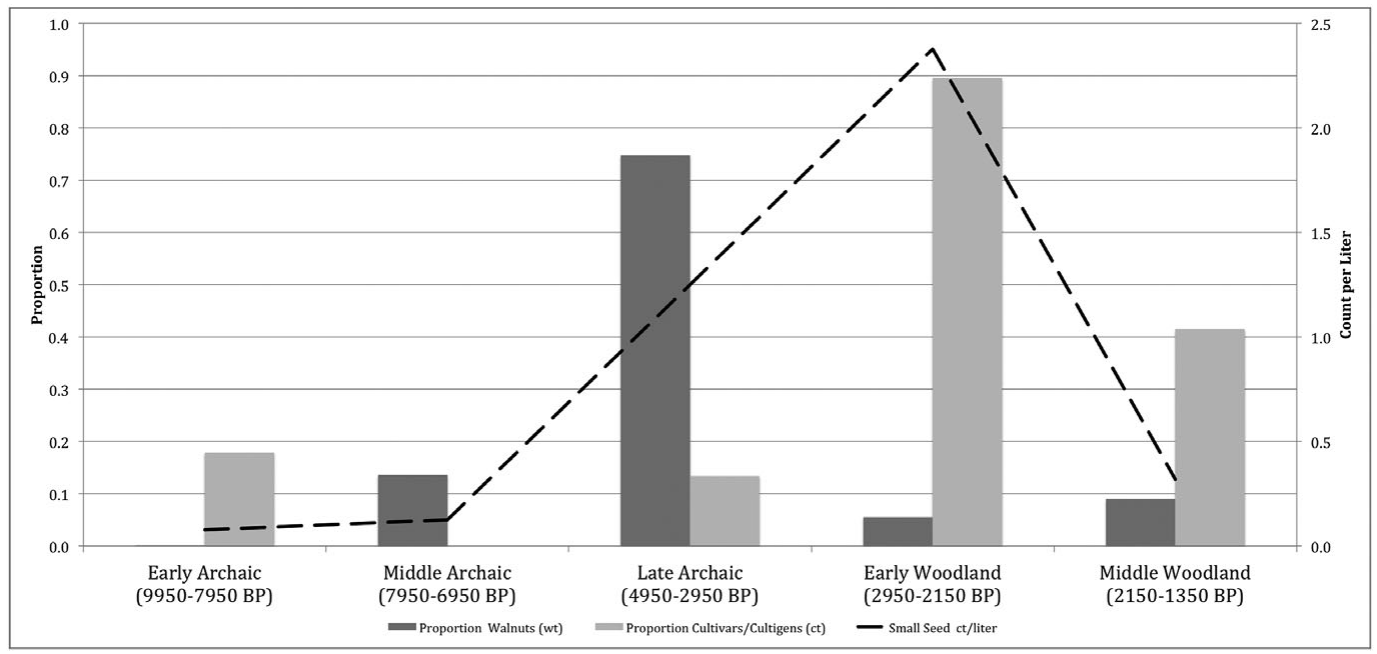

Figure 6. Temporal trends in Little Tennessee River archaeobotanical assemblages.

reaches a maximum of 75 percent of total nut weight in Late Archaic components (88.5 percent at the Iddins site), accompanied by an increase in seed count ( 1.25 seeds/liter) with a low proportion of cultigen seeds (13 percent). These trends correspond to palynological evidence indicating clearance of bottomland forests and increased use of upland trees for fuel (Jefferson et al. 1982). Walnut drops off to 6 percent in the Early Woodland coincident with increased abundance of seeds (2.4 seeds/liter) and increased proportion of cultigens ( 90 percent), including the earliest maize macrofossils in the region (Chapman and Shea 1981). These trends accompany a shift from mobile, low-density hunting and gathering camps to sedentary occupations by larger populations (Davis 1990).

\section{Tombigbee River}

The Tombigbee Basin falls outside the area usually recognized for cultivation of EAC domesticates (Fritz 1993; Gremillion 2002a). Nonetheless, similar but later trends are evident in the relative occurrence of walnuts and seeds as foragers shifted to a sedentary, agricultural lifestyle (Caddell 1981, 1982a, 1982b). Palynological evidence indicates increased clearance of bottomland species beginning about 2400 B.P. (Whitehead and Sheehan 1985). Walnuts are best represented in Middle Woodland features, comprising over 5 percent of total nut weight, but drop to only .04 percent in the Late Woodland (multiplied by 10 in Figure 7). The peak walnut occurrence is coincident with an increase in both small seed count (1.8 seeds/liter) and percentage of cultigens (76 percent). Although seed counts decline in the Late Woodland (.5 seeds/liter), they remain dominated by indigenous cultigens (74 percent) and marked by the earliest occurrence of maize in the region (occurring in 10 percent of samples). Once again, these trends accompany a transition from short-term seasonal encampments to sedentary villages, apparently in the context of population growth (Jenkins and Krause 2002).

\section{Duck River}

The archaeobotanical assemblage from the Duck River differs from the others in seed and walnut representation. Walnut shell is found only in trace amounts in Middle Archaic contexts of the Hayes site, which also produced some of the earliest dated Cucurbita rind fragments and domesticated Helianthus seeds in the eastern United States (Crites 1987a; Smith 2011). This site is not included in Figure 8 because the sample was taken from a stratigraphic column rather than from feature contexts. For subsequent materials (Crites 1978, 1985, 1987b; McMahan 1983), there is a dramatic rise in small seed and cultigen 


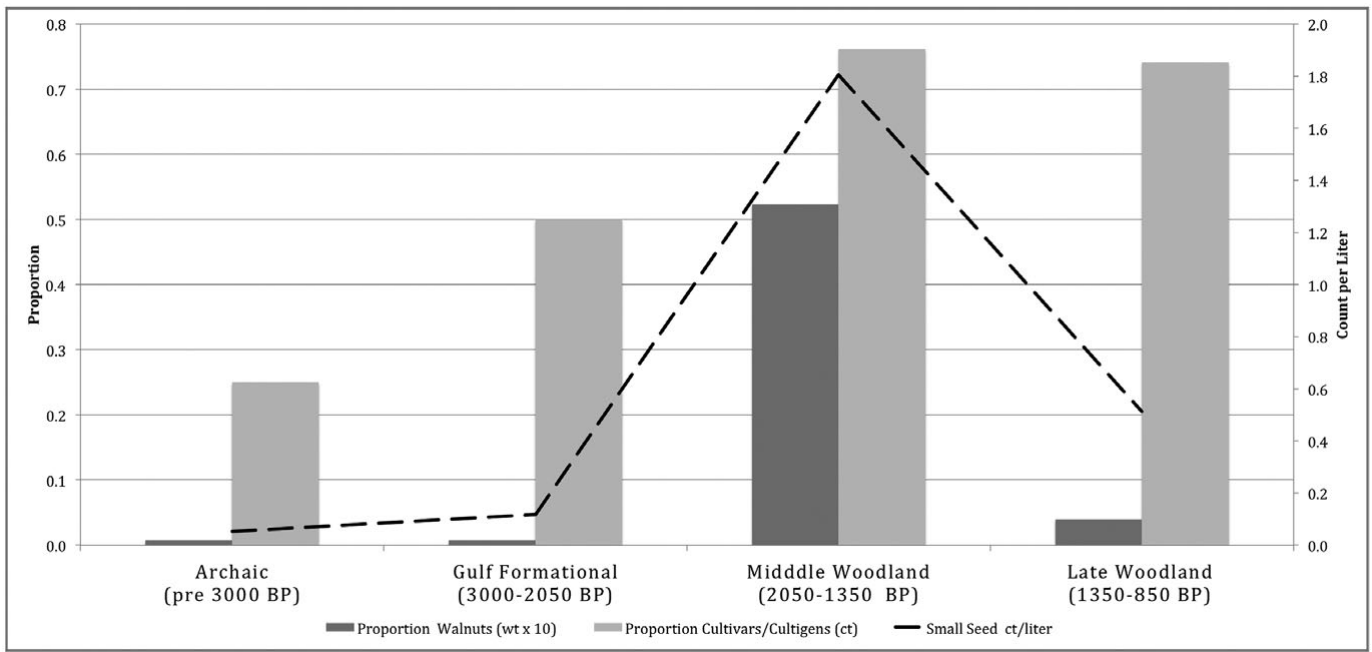

Figure 7. Temporal trends in Tombigbee River archaeobotanical assemblages.

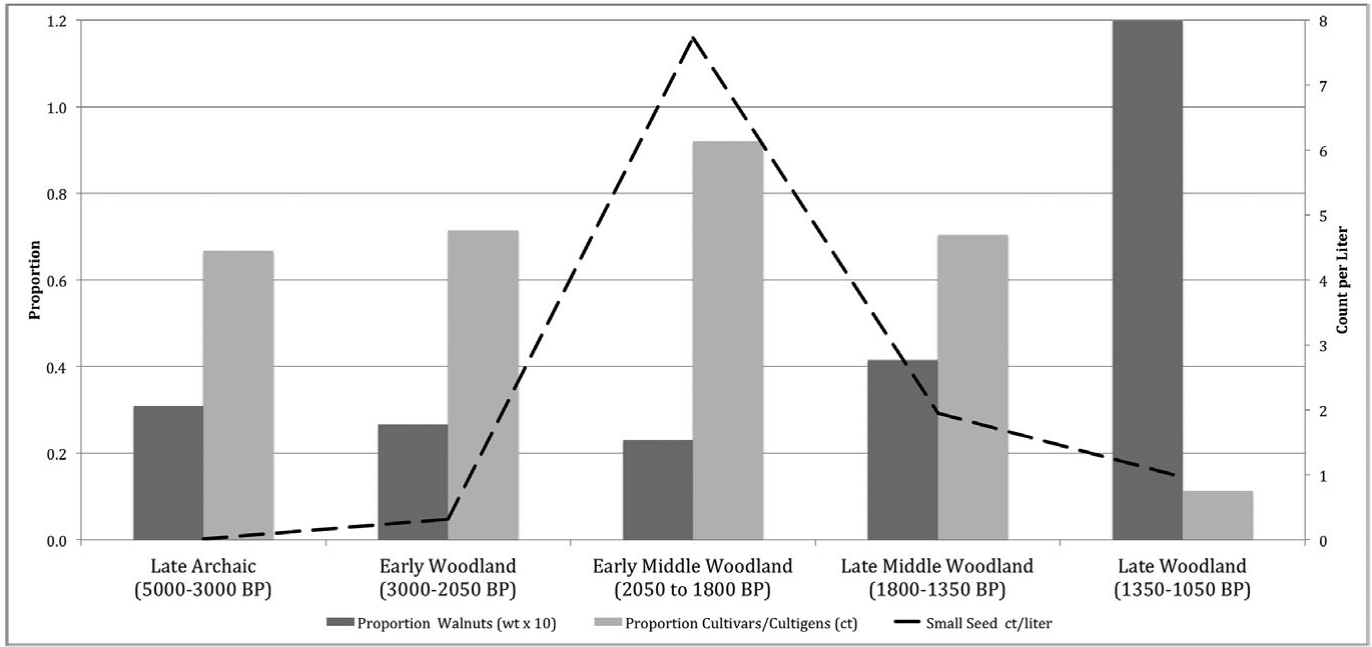

Figure 8. Temporal trends in Duck River archaeobotanical assemblages.

counts beginning in the Early Middle Woodland (7.7 seeds/liter with 92 percent cultigens), but they decline to lows in the Late Woodland of only one seed per liter and 11 percent cultigens. Walnut proportions are again multiplied by 10 in Figure 8. Overall proportions of walnut are relatively low, but they increase from the Early Middle Woodland until reaching a peak of 12 percent in the Late Woodland period, after the peak representation of seed counts and cultigens. Duck River subsistence-settlement strategies shifted from a transient Late Archaic foraging pattern to a sedentary pattern in the Middle Woodland and returned to more mobile foraging occupations in the Late Woodland (Kline et al. 1982). Since peak walnut use is associated with a resurgence of mobile foraging, I suggest that Late Woodland folk harvested walnuts from revegetated seed plots. The relationship between seed cultivation and walnut use is broadly similar to those posed in the marginal value model (increasing through and peaking following a decline in seed cultivation), so I count it as consistent, but less robustly so, with my hypothesis. 


\section{Summary}

The archaeological records of all four regions include contexts where low-ranked walnuts were intensively used for limited periods, consistent with intensified use of local resources in anthropogenic niches during the EAC. I interpret this as broad-spectrum foraging in anthropogenic habitat mosaics where resources from nearby early (seed grains) and late (walnut) successional communities were stored to supplement populationinduced shortfalls of the hickory crop. Note that the patterns in the Tombigbee valley, American Bottom, and the Little Tennessee River valley are similar even though they are not contemporary. Walnut use intensifies either "prior to or concomitant with" an increase in use of small grain-seeds, suggesting intentional seed cultivation. As such, these cases both meet Smith's (2015:240) most direct criterion of evidence for anthropogenic niche construction, and are consistent with predictions of the marginal value model of hickory transport (Figure 4). This argues strongly that the three test cases reflect similar economic foraging decisions made as burning induced the emergence of anthropogenic niches, and are certainly consistent with local population-induced reductions of mobility and access to mast resources.

\section{Conclusions}

A critical weakness of Smith's formulation of $\mathrm{CNC}$ is its inability to predict economic decisionmaking by foragers, preventing it from specifying any adaptive advantages of horticultural subsistence strategies beyond mere increases in food abundance. Yet why foragers shifted to agriculture where and when they did is the very question that archaeologists want to answer, and understanding why proto-domesticates transitioned from inadvertent beneficiaries of niche construction to objects of intentional resource enhancement is surely fundamental to any understanding of agricultural origins based on CNC. This is the strength of optimal foraging models employed as a research strategy. Foraging models grounded in behavioral ecology make explicit links between evolutionary theory and empirical aspects of the archaeological record. They allow theoretical concepts like resource intensifica- tion and niche construction to be simplified to measurable aspects of forager economy such as travel, search, and handling times, diminishing returns, and so on. These can either be observed among contemporary foragers or experimentally replicated, and insights gained can then be tested against the archaeological record.

Contrary to Smith's criticisms, optimal foraging models neither inherently deny niche construction nor are intrinsically linked to the resource depression hypothesis alone. Instead, such models provide frameworks under which the economic causes and consequences of niche construction can be investigated by fleshing out different expectations for resource enhancement or depression. The latter should be marked by increased use of resources with returns as low as or lower than cultivated seeds, whereas the former should accompany diminished use of such low-return, non-cultivated resources. I find evidence for an initial intensification of walnut usage followed by a contraction as seed yields were enhanced in this analysis of mast and seed procurement strategies. This illustrates how optimal foraging models serve heuristically in a context of niche construction, to clarify correlations between nut use and seed cultivation that archaeologists have long noted, but were illequipped to formulate testable hypotheses about the economic linkages between the two procurement systems. Anyone interested in exploring how the economic context of prehistoric foraging decisions led to agriculture, within a niche construction framework, will find optimal foraging models useful tools.

Acknowledgments. Stephen Carmody, Brian Codding, Kathy Heath, Kandace Hollenbach, Keith Little, Gerald Schroedl, David Hurst Thomas, Elic Weitzel, Bruce Winterhalder, the University of Utah Archaeological Center lab group, and three anonymous reviewers made many useful comments on this paper. Bridget Wall and Jennifer Mak provided key support in preparing figures and compiling databases. Joyce Bishop, Adolfo F. Gil, and Martin Biskowski translated the abstract into Spanish, which was checked by Roxana Cattaneo. Jim O'Connell and Duncan Metcalfe deserve recognition for enduring various paleo versions of this paper. The author alone is responsible for any errors in content.

Data Availability Statement. All data used for this research are available by contacting the author. 


\section{References Cited}

Abrams, Marc D., and Gregory J. Nowacki

2008 Native Americans as Active and Passive Promoters of Mast and Fruit Trees in the Eastern USA. Holocene 18:1123-1137.

Anderson, David G., Michael Russo, and Kenneth E. Sassaman

2007 Mid-Holocene Cultural Dynamics in Southeastern North America. In Climate Change and Cultural Dynamics, edited by David G. Anderson, Kirk A. Maasch, and Daniel H. Sandweiss, pp. 457-489. Academic Press, San Diego.

Anderson, David G., and Kenneth E. Sassaman

2012 Recent Developments in Southeastern Archaeology: From Colonization to Complexity. Society for American Archaeology Press, Washington, D.C.

Asch, Nancy. B., and David L. Asch

1978 The Economic Potential of Iva Annua and its Prehistoric Importance in the Lower Illinois Valley. In The Nature and Status of Ethnobotany, edited by Richard I. Ford and Volney H. Jones. Museum of Anthropology Anthropological Papers no. 67, University of Michigan, Ann Arbor.

Barlow, Renee K., and Duncan Metcalfe

1996 Plant Utility Indices: Two Great Basin Examples. Journal of Archaeological Science 23:351271

Bettinger, Robert L.

2009 Hunter-Gatherer Foraging: Five Simple Models. Eliot Werner Publications, Clinton Corners, New York.

Bettinger, Robert L., and Mark N. Grote

2016 Marginal Value Theorem, Patch Choice, and Human Foraging Response in Varying Environments. Journal of Anthropological Archaeology 42:79-87.

Bettinger, Robert L., Ripan Malhi, and Helen McCarthy 1997 Central Place Models of Acorn and Mussel Processing. Journal of Archaeological Science 24:887-899.

Binford, Lewis R.

1968 Post-Pleistocene Adaptions. In New Perspectives in Archeology, edited by Sally Binford and Lewis Binford, pp. 313-341. Aldine, Chicago.

Bird, Douglas W., and James F. O'Connell

2012 Human Behavioral Ecology. In Archaeological Theory Today, 2nd ed., edited by Ian Hodder, pp. 37-61. Polity Press, Cambridge.

Black, Bryan A., and Marc D. Abrams

2001 Influences of Native Americans and Surveyor Biases on Metes and Bounds Witness-Tree Distribution. Ecology 82:2574-2586.

Braidwood, Robert J.

1960 The Agricultural Revolution. Scientific American 203:130-148.

Brown, James A., and Robert K. Vierra

1983 What Happened in the Middle Archaic? Introduction to an Ecological Approach to Koster Site Archaeology. In Archaic Hunters and Gatherers in the American Midwest, edited by James L. Phillips and James A. Brown, pp. 165-197. Academic Press, New York.

Buikstra, Jane E., Lyle W. Konigsberg, and Jill Bullington 1986 Fertility and the Development of Agriculture in the Prehistoric Midwest. American Antiquity 51:528-546.

Caddell, May Gloria

1981 Plant Resources, Archaeological Plant Remains, and Prehistoric Plant-Use Patterns in the Central
Tombigbee River Valley. In Biocultural Studies in the Gainesville Lake Area. Archaeological Investigations in the Gainesville Lake Area of the Tennessee-Tombigbee Waterway, Vol. IV, Report of Investigations No. 14, Office of Archaeological Research, edited by Gloria M. Caddell, Anne Woodrick, and Mary C. Hill. University of Alabama, Tuscaloosa.

1982a Plant Resources, Archaeological Plant Remains, and Prehistoric Plant-Use Patterns in the Central Tombigbee River Valley. Bulletin 7, Alabama Museum of Natural History. University of Alabama, Tuscaloosa.

1982b Plant Remains from the Yarborough Site. In Archaeological Investigations at the Yarborough Site (22 CL 814), edited by Carlos Solis and Richard Walling, pp. 134-140. Report of Investigations No. 30, Office of Archaeological Research, University of Alabama, Tuscaloosa.

Cane, Scott

1987 Australian Aboriginal Subsistence in the Western Desert. Human Ecology 15:391-434.

Carmody, Stephen Byrnes

2010 Middle Archaic Foraging Adaptations in Northwest Alabama: A Case Study from Dust Cave. Journal of Alabama Archaeology 56:3-28.

2014 From Foraging to Food Production on the Southern Cumberland Plateau of Alabama and Tennessee, U.S.A. Ph.D. dissertation, Department of Anthropology, University of Tennessee, Knoxville.

Chapman, Jefferson, and Andrea Brewer Shea

1981 The Archaeobotanical Record to Contact in the Lower Little Tennessee River Valley. Tennessee Anthropologist 6:61-84.

Charnov, Eric., and Gordon H. Orians

1973 Optimal Foraging: Some Theoretical Explorations. Electronic document, http://ir.library. oregonstate.edu/xmlui/bitstream/handle/1957/53364/ CharnovEL-OptimalForaging.pdf?sequence $=1$, accessed October 23, 2016.

Christenson, Andrew L.

1980 Change in the Human Food Niche in Response to Population Growth. In Modeling Change in Prehistoric Subsistence Economies, edited by Timothy K. Earle and Andrew L. Christenson, pp. 31-72. Academic Press, New York.

1986 A Microeconomic View of Archaic Subsistence in the Oak-Hickory Forest. In Foraging, Collecting, and Harvesting: Archaic Period Subsistence and Settlement in The Eastern Woodlands, edited by Sarah W. Neusius, pp. 33-63. Center for Archaeological Investigations, Southern Illinois University at Carbondale.

Claassen, Cheryl

2010 Feasting with Shellfish in the Southern Ohio Valley: Archaic Sacred Sites and Rituals. University of Tennessee Press, Knoxville.

Codding, Brian F., and Douglas W. Bird

2015 Behavioral Ecology and the Future of Archaeological Science. Journal of Archaeological Science 56:920.

Cohen, Mark N.

1977 The Food Crisis in Prehistory: Overpopulation and the Origins of Agriculture. Yale University Press, New Haven.

Cowan, C. Welsey, H. Edwin Jackson, Katherine Moore, Andrew Nickelhoff, and Tristine L. Smart 
1981 The Cloudsplitter Rockshelter, Menifee County, Kentucky: A Preliminary Report. Southeastern Archaeological Conference Bulletin 24:60-76.

Crites, Gary D.

1978 Paleoethnobotany of the Normandy Reservoir in the Upper Duck River Valley, Tennessee. Unpublished Master's thesis, Department of Anthropology, University of Tennessee, Knoxville.

1985 Middle Woodland Paleoethnobotany of the Eastern Highland Rim of Tennessee: An Evolutionary Perspective on Change in Human-Plant Interaction. Unpublished Ph.D. dissertation, Department of Anthropology, University of Tennessee, Knoxville.

1987a Middle and Late Holocene Ethnobotany of the Hayes Site (40ml139): Evidence from Unit 990N918E. Midcontinental Journal of Archaeology 12:3-32.

1987b Human-Plant Mutualism and Niche Expression in the Paleoethnobotanical Record: A Middle Woodland Example. American Antiquity 52:725-740.

Davis, R.P. Stephen

1990 Aboriginal Settlement Patterns in the Little Tennessee River Valley. Report of Investigations, Department of Anthropology, No. 50. University of Tennessee, Knoxville.

Delcourt, Paul A., Hazel R. Delcourt, Cecil R. Ison, William E. Sharp, and Kristen J. Gremillion

1998 Prehistoric Human Use of Fire, the Eastern Agricultural Complex, and Appalachian Oak-Chestnut Forests: Paleoecology of Cliff Palace Pond, Kentucky. American Antiquity 63:263-278.

Flannery, Kent V.

1969 Origins and Ecological Effects of Early Domestication in Iran and the Near East. In The Domestication and Exploitation of Plants and Animals, edited by Peter J. Ucko, pp. 73-100. Aldine, Chicago.

Fritz, Gayle J.

1993 Early and Middle Woodland Period Paleoethnobotany. In Foraging and Farming in the Eastern Woodlands, edited by Christine M. Scarry, pp. 39-56. University Press of Florida, Gainesville.

1997 A Three-Thousand-Year-Old Cache of Crop Seeds from Marble Bluff, Arkansas. In People, Plants, and Landscapes: Studies in Paleoethnobotany, edited by Kristin J. Gremillion, pp. 43-62. University of Alabama Press, Tuscaloosa.

Gardner, Paul S.

1997 The Ecological Structure and Behavioral Implications of Mast Exploitation Strategies. In People, Plants, and Landscapes: Studies in Paleoethnobotany, edited by Kristin J. Gremillion, pp. 161-178. University of Alabama Press, Tuscaloosa.

Gremillion, Kristen J.

1998 Changing Roles of Wild and Cultivated Plant Resources among Early Farmers of Eastern Kentucky. Southeastern Archaeology 17:140-157.

2002a The Development and Dispersal of Agricultural Systems in the Woodland Period Southeast. In The Woodland Southeast, edited by David G. Anderson and Robert C. Mainfort, pp. 483-581. University of Alabama Press, Tuscaloosa.

2002b Foraging Theory and Hypothesis Testing in Archaeology: An Exploration of Methodological Problems and Solutions. Journal of Anthropological Archaeology 21:142-164.

2003 Eastern Woodland Overview. In People and Plants in Ancient Eastern North America, edited by Paul
E. Minnis, pp. 17-49. Smithsonian Books, Washington, D.C.

2004 Seed Processing and the Origins of Food Production in Eastern North America. American Antiquity 69:215233.

2006 Central Place Foraging and Food Production on the Cumberland Plateau, Eastern Kentucky. In Behavioral Ecology and the Transition to Agriculture, edited by Douglas J. Kennett and Bruce Winterhalder, pp. 41-62. University of California Press, Berkeley.

2015 Prehistoric Upland Farming, Fuelwood, and Forest Composition on the Cumberland Plateau, Kentucky, USA. Journal of Ethnobiology 35:60-84.

Gremillion, Kristen J., Loukas Barton, and Dolores Piperno

2014 Particularism and the Retreat from Theory in the Archaeology of Agricultural Origins. Proceedings of the National Academy of Sciences 111(17):61716177.

Gremillion, Kristen J., Jason Windingstad, and Sarah C. Sherwood

2008 Forest Opening, Habitat Use, and Food Production on the Cumberland Plateau, Kentucky: Adaptive Flexibility in Marginal Settings. American Antiquity 73:387411.

Hollenbach, Kandace D.

2009 Foraging the Tennessee River Valley, 12,500 to 8,000 Years Ago. University of Alabama Press, Tuscaloosa.

Homsey-Messer, Lara K.

2015 Revisiting the Role of Caves and Rockshelters in the Hunter-Gatherer Taskscape of the Archaic Midsouth. American Antiquity 80:332-352.

Homsey, Lara K., Renee B. Walker, and Kandace D. Hollenbach

2010 What's for Dinner? Investigating Food-Processing Technologies at Dust Cave, Alabama. Southeastern Archaeology 29:182-196.

Jefferies, Richard W.

2009 Holocene Hunter-Gatherers of the Lower Ohio River Valley. University of Alabama Press, Tuscaloosa.

Jefferson, Chapman, Paul A. Delcourt, Patricia A. Cridlebaugh, Andrea B. Shea, and Hazel R. Delcourt

1982 Man-Land Interaction: 10,000 Years of American Indian Impact on Native Ecosystems in The Lower Little Tennessee River Valley, Eastern Tennessee. Southeastern Archaeology 1:115-121.

Jenkens, Ned J.

1974 Subsistence and Settlement Patterns in the Western Tennessee Valley during the Transitional ArchaicWoodland Period. Journal of Alabama Archaeology 20:183-193.

Jenkins, Ned J., and Richard A. Krause

2002 The Tombigbee Watershed in Southeastern Prehistory. University of Alabama Press, Tuscaloosa.

Johannessen, Sissel

1983 Floral Remains from the Early Woodland Florence Phase. In The Florence Street Site (11-S-458), edited by Thomas E. Emerson, George R. Milner, and D. K. Jackson, pp. 133-143. Published for the Illinois Dept. of Transportation by the University of Illinois Press, Champaign.

1984 Paleoethnobotany. In American Bottom Archaeology: a Summary of the FAI-270 Project Contribution to the Culture History of the Mississippi River Valley, edited by Charles J. Bareis and James W. Porter, pp. 197-214. Published for the Illinois Dept. of Transportation by the University of Illinois Press, Urbana. 
Keegan, William F., and Brian M. Butler

1987 The Microeconomic Logic of Horticultural Intensification in the Eastern Woodlands. In Emergent Horticultural Economies of the Eastern Woodlands, edited by William F. Keegan, pp. 109-127. Occasional Papers No. 7, Center for Archaeological Investigations, Southern Illinois University, Carbondale.

Keller, John E.

1987 Prehistoric Subsistence and Hardwood Nut Yields. Midcontinental Journal of Archaeology 12:175192.

Kelly, John E.

2002 Woodland Period Archaeology in the American Bottom. In The Woodland Southeast, edited by David G. Anderson and Robert C. Mainfort, pp 134-161. University of Alabama Press, Tuscaloosa.

Kline, Gerald W., Gary D. Crites, and Charles H. Faulkner 1982 The McFarland Project: Early Middle Woodland Settlement and Subsistence in the Upper Duck River Valley in Tennessee. Miscellaneous Paper No. 8. Tennessee Anthropological Association, Knoxville.

Knott, Laura L.

1981 The Botanical Remains from Phipps Bend. In The Phipps Bend Archaeological Project. Research Series No. 3, edited by Robert H. Lafferty, pp. 397-410. Office of Archaeological Research. University of Alabama, Tuscaloosa.

Koenig, Walter D., and Johannes M. H. Knops

2005 The Mystery of Masting in Trees. American Scientist 93:340-347.

López, Laura M., Aylen Capparelli, and Axel Emil Nielsen

2011 Traditional Post-Harvest Processing to Make Quinoa Grains (Chenopodium quinoa var. quinoa) Apt for Consumption in Northern Lipez (Potosí, Bolivia): Ethnoarchaeological and Archaeobotanical Analyses. Archaeological and Anthropological Sciences 3:49_ 70 .

McMahan, J. David

1983 Paleoethnobotany of the Late Woodland Mason Phase in the Elk and Duck River Valleys, Tennessee. Unpublished Master's thesis, Department of Anthropology, University of Tennessee, Knoxville.

Marquardt, William H., and Patty Jo Watson

2005 Archaeology of the Middle Green River Region, Kentucky. Institute of Archaeology and Paleoenvironmental Studies, University of Florida, Gainesville.

Miller, D. Shane

2014 From Colonization to Domestication: A Historical Ecological Analysis of Paleoindian and Archaic Subsistence and Landscape Use in Central Tennessee. Ph.D. dissertation, Department of Anthropology, University of Arizona, Tucson.

Moore, Christopher R., and Victoria G. Dekle

2010 Hickory Nuts, Bulk Processing, and the Advent of Early Horticultural Economies in Eastern North America. World Archaeology 42:595-608.

Munson, Patrick J.

1986 What Happened in the Archaic in the Midwestern United States. Reviews in Anthropology 13:276282.

Neumann, Thomas W.

2002 The Role of Prehistoric Peoples in Shaping Ecosystems in the Eastern United States: Implications for Restoration Ecology and Wilderness Management. In Wilderness and Political Ecology: Aboriginal Influences and the Original State of Nature, edited by Charles Kay and Randy T. Simmons, pp. 141-178. University of Utah Press, Salt Lake City.

Nixon, Charles M., Milford W. McClain, and Robert W. Donohoe

1975 Effects of Hunting and Mast Crops on a Squirrel Population. Journal of Wildlife Management 39:125.

Nixon, Charles M., Milford W. McClain, and Lonnie P. Hansen

1980 Six Years of Hickory Seed Yields in Southeastern Ohio. Journal of Wildlife Management 44:534539.

O'Brien, Michael J., David P. Braun, Bennet Bronson, Douglas K. Charles, Robert C. Dunnell, George R. Milner, and David Rindos

1987 Sedentism, Population Growth, and Resource Selection in the Woodland Midwest: A Review of Coevolutionary Developments. Current Anthropology 28:177197.

Petruso, Karl M., and Jere M. Wickens

1984 The Acorn in Aboriginal Subsistence in Eastern North America. In Experiments and Observations on Aboriginal Wild Plant Food Utilization in Eastern North America, edited by Patrick J. Munson, pp. 360-378. Indiana Historical Society, Indianapolis.

Purtill, Mathew P.

2008 Down by the River: Late Archaic through Terminal Archaic Dynamics at the Davisson Farm Site (33LE619), Lawrence County, Ohio. In Transitions: Archaic and Early Woodland Research in the Ohio Country, edited by Martha P. Otto and Brian G. Redmond, pp. 41-78. Ohio University Press, Athens.

Reidhead, Van A.

1981 A Linear Programming Model of Prehistoric Subsistence Optimization: A Southeastern Indiana Example. Indiana Historical Society, Indianapolis.

Rossen, Jack

2006 Archaeobotanical Remains. In The Highland Creek Site: Middle to Late Archaic Wetland Utilization in Western Kentucky, edited by Greg Maggard and David Pollack, pp. 73-84. Research Report No. 5, Kentucky Archaeological Survey, Lexington.

Scarry, C. Margaret

2003 Patterns of Wild Plant Utilization in the Prehistoric Eastern Woodlands. In People and Plants in Ancient Eastern North America, edited by Paul E. Minnis, pp. 50-104. Smithsonian Books, Washington, D.C.

Schlesinger, Richard C., and David T. Funk

1977 Manager's Handbook for Black Walnut. General Technical Report NC-38. North Central Forest Experiment Station, Forest Service, U.S. Department of Agriculture, St. Paul, Minnesota.

Schoener, Thomas W.

1971 Theory of Feeding Strategies. Annual Review of Ecology and Systematics 2:369-404.

Seeman, Mark F., and Hugh D. Wilson

1984 The Food Potential of Chenopodium for the Prehistoric Midwest. In Experiments and Observations on Aboriginal Wild Plant Food Utilization in Eastern North America, edited by Patrick J. Munson, pp. 299-316. Indiana Historical Society, Indianapolis.

Simms, Steven R.

1987 Behavioral Ecology and Hunter-Gatherer Foraging: An Example From the Great Basin. BAR International Series, 381. Oxford. 
Simon, Mary L.

2009 A Regional and Chronological Synthesis of Archaic Period Plant Use in the Midcontinent. In Archaic Societies: Diversity and Complexity across the Midcontinent, edited by Thomas E. Emerson, Dale L. McElrath and Andrew C. Fortier, pp. 81-114. State University of New York Press, Albany.

Simon, Mary L., and Kathryn E. Parker

2006 Prehistoric Plant Use in the American Bottom: New Thoughts and Interpretations. Southeastern Archaeology 25:212-257.

Smith, Bruce D.

1987a The Independent Domestication of Indigenous Seed-Bearing Plants in Eastern North America. In Emergent Horticultural Economies of the Eastern Woodlands, edited by William F. Keegan, pp. 348. Occasional Paper No. 7. Center for Archaeological Investigations, Southern Illinois University Carbondale.

1987b The Economic Potential of Chenopodium berlandieri in Prehistoric Eastern North America. Journal of Ethnobiology 7:29-54.

1989 Origins of Agriculture in Eastern North America. Science 246(4937):1566-1571.

1992 The Economic Potential of Iva Annua in Prehistoric Eastern North America. In Rivers of Change: Essays on Early Agriculture in Eastern North America, edited by Bruce D. Smith, pp. 185-200. Smithsonian Institution Press, Washington, D.C.

1995 Seed Plant Domestication in Eastern North America. In Last Hunters, First Farmers: New Perspectives on The Prehistoric Transition to Agriculture, edited by T. Douglas Price and Anne Birgitte Gebauer, pp. 193-204. School of American Research Press, Santa Fe.

2001 Low-Level Food Production. Journal of Archaeological Research 9(1):1-43.

2006 Eastern North America as an Independent Center of Plant Domestication. Proceedings of the National Academy of Sciences 103(33):12223-12228.

2009a Resource Resilience, Human Niche Construction, and the Long-Term Sustainability of Pre-Columbian Subsistence Economies in the Mississippi River Valley Corridor. Journal of Ethnobiology 29:167183.

2009b Core Conceptual Flaws in Human Behavioral Ecology. Communicative and Integrative Biology 2:533534.

2011 The Cultural Context of Plant Domestication in Eastern North America. Current Anthropology 52(S4):S471-S484.

2015 A Comparison of Niche Construction Theory and Diet Breadth Models as Explanatory Frameworks for the Initial Domestication of Plants and Animals. Journal of Archaeological Research 23:215-262.

Smith, Bruce D., and Richard A. Yarnell

2009 Initial Formation of an Indigenous Crop Complex in Eastern North America at 3800 B.P. Proceedings of the National Academy of Sciences 106(16):6561-6566.

Smith, Kimberly G., and Todd Scarlett

1987 Mast Production and Winter Populations of RedHeaded Woodpeckers and Blue Jays. Journal of Wildlife Management 51:459-467.

Stafford, C. Russell

1991 Archaic Period Logistical Foraging Strategies in West-Central Illinois. Midcontinental Journal of Archaeology 16:212-246.

1994 Structural Changes in Archaic Landscape Use in the Dissected Uplands of Southwestern Indiana. American Antiquity 59:219-237.

Stapanian, Martin A., and Christopher C. Smith

1978 A Model for Seed Scatterhoarding: Coevolution of Fox Squirrels and Black Walnuts. Ecology 59:884 896.

Talalay, Laurie, Donald R. Keller, and Patrick J. Munson

1984 Hickory Nuts, Walnuts, Butternuts, and Hazelnuts. In Experiments and Observations on Aboriginal Wild Plant Food Utilization in Eastern North America, edited by Patrick J. Munson, pp. 338-359. Indiana Historical Society, Indianapolis.

Thomas, David H.

2008 Native American Landscapes of St. Catherine's Island, Georgia: The Theoretical Framework. Anthropological Papers Vol. 88, Pt. 1. American Museum of Natural History, New York.

Tushingham, Shannon, and Robert L. Bettinger

2013 Why Foragers Choose Acorns Before Salmon: Storage, Mobility, and Risk in Aboriginal California. Journal of Anthropological Archaeology 32:527-537.

U.S. Department of Agriculture

2015 Fire Effects Information System Database. November 2015 ed. Electronic document, http://www. feis-crs.org/beta/, accessed October 22, 2016.

U.S. Geological Survey

1999 Digital representation of "Atlas of United States Trees" by Elbert L. Little, Jr. November 2015 ed. Electronic document, http://gec.cr.usgs.gov/data/little, accessed October 22, 2016.

Wagner, Gail R.

2003 Eastern Woodland Anthropogenic Ecology. In People and Plants in Ancient Eastern North America, edited by Paul E. Minnis, pp. 126-171. Smithsonian Books, Washington, D.C.

2005 Anthropogenic Changes in the Carlston Annis Site. In Archaeology of the Middle Green River Region, Kentucky, edited by William H. Marquardt and Patty J. Watson, pp. 213-242. Institute of Archaeology and Paleoenvironmental Studies, University of Florida, Gainesville.

Watson, Patty Jo.

1985 The Impact of Early Horticulture in the Upland Drainages of the Midwest and Midsouth. In Prehistoric Food Production in North America, edited by Richard Ford, pp. pp. 99-147. Anthropological Papers No. 75. University of Michigan, Museum of Anthropology, Ann Arbor.

Weitzel, Elic M., and Brian F. Codding

2016 Population Growth as a Driver of Initial Domestication in Eastern North America. Royal Society Open Science 3:160319. DOI: 10.1098/rsos.160319.

Whitehead, Donald R., and Mark C. Sheehan

1985 Holocene Vegetational Changes in the Tombigbee River Valley, Eastern Mississippi. American Midland Naturalist 113:122-137.

Winterhalder, Bruce, and Carol Goland

1997 An Evolutionary Ecology Perspective on Diet Choice, Risk, and Plant Domestication. In People, Plants, and Landscapes: Studies in Paleoethnobotany, edited by Kristin J. Gremillion, pp. 123-160. University of Alabama Press, Tuscaloosa.

Winterhalder, Bruce, and Douglas J. Kennett

2006 Behavioral Ecology and the Transition from Hunting and Gathering to Agriculture. In Behavioral Ecology 
and the Transition to Agriculture, edited by Douglas J. Kennett and Bruce Winterhalder, pp. 1-21. University of California Press, Berkeley.

Winters, Howard D.

1969 The Riverton Culture: A Second Millennium Occupation in the Central Wabash Valley. Monograph No. 1.; Reports of Investigations, No. 13. Illinois State Museum, Illinois Archaeological Survey, Springfield.

Wykoff, M. William

1991 Black Walnut on Iroquoian landscapes. Northeastern Indian Quarterly 4:4-17.

Yarnell, Richard A.

2004 Riverton Plant Remains and Terminal Archaic Crops. In Aboriginal Ritual and Economy in the Eastern Woodlands: Essays in Memory of Howard Dalton Winters, edited by Anne-Marie Cantwell, Lawrence A. Conrad, and Jonathan E. Reyman, pp. 123-132. Scientific Papers Vol. 30; Kampsville Studies in Archeology and History, No. 5. Illinois State Museum, Kampsville.

Yarnell, Richard A., and M. Jean Black

1985 Temporal Trends Indicated by a Survey of Archaic and Woodland Plant Food Remains from Southeastern North America. Southeastern Archaeology 4:93106.

Zawacki, April A., and Glenn Hausfater

1969 Early Vegetation of the Lower Illinois Valley. Research Papers, Vol. 1. Illinois State Museum, Springfield.

Zeanah, David W.

2002 Central Place Foraging and Prehistoric Pinyon Utilization in the Great Basin. In Beyond Foraging and Collecting: Evolutionary Change in HunterGatherer Settlement Systems, edited by Ben Fitzhugh and Junko Habu, pp. 231-256. Springer US, Boston, Massachusetts.

Zeanah, David W., Brian F. Codding, Douglas W. Bird, Rebecca Bliege Bird, and Peter M. Veth

2015 Diesel and Damper: Changes in Seed Use and Mobility Patterns Following Contact Amongst the Martu of Western Australia. Journal of Anthropological Archaeology 39:51-62.
Zeder, Melinda A.

2012 The Broad Spectrum Revolution at 40: Resource Diversity, Intensification, and an Alternative to Optimal Foraging Explanations. Journal of Anthropological Archaeology 31:241-264.

\section{Notes}

1. Calibrated date ranges for regional cultural periods follow Anderson and Sassaman (2012). Date ranges for Figures 5-8 follow local authors as cited.

2. I assume that partial field processing to improve the utility of a transported load of hickory would not be worthwhile given the travel thresholds predicted by the model (less than $5 \mathrm{~km}$ from a central place). Nonetheless, modeling and experimentation demonstrate that field processing improves the rate that California acorns (Bettinger et al. 1997) and Great Basin piñon and pickleweed seeds (Barlow and Metcalfe 1996) can be transported back to central places over longer distances. Actualistic experiments on the effects of field processing on hickory and chenopod transportability would be informative and likely have archaeologically testable implications.

3. Butternut is not easily distinguished from black walnut in archaeobotanical assemblages. Butternut offers even lower returns than black walnut, so confusion of shell makes no difference in regard to prediction of very lowranked mast procurement. Although closely related to black walnut, butternut is less fire tolerant, so may not be as closely associated with anthropogenic fire regimes. Since all the archaeobotanical assemblages discussed in this paper occur within the natural distribution of walnut, whereas some occur outside the distribution of butternut (U.S. Geological Survey 1999). I assume that fire-sensitive black walnut makes up the bulk of Juglans shell in these assemblages, accounting for temporal trends observed.

Submitted July 21, 2016; Revised September 20, 2016; Accepted September 25, 2016 